Prepared for the U.S. Department of Energy under Contract DE-AC05-76RL01830

\title{
Energy Efficiency Potential in Existing Commercial Buildings: Review of Selected Recent Studies
}

DB Belzer

April 2009

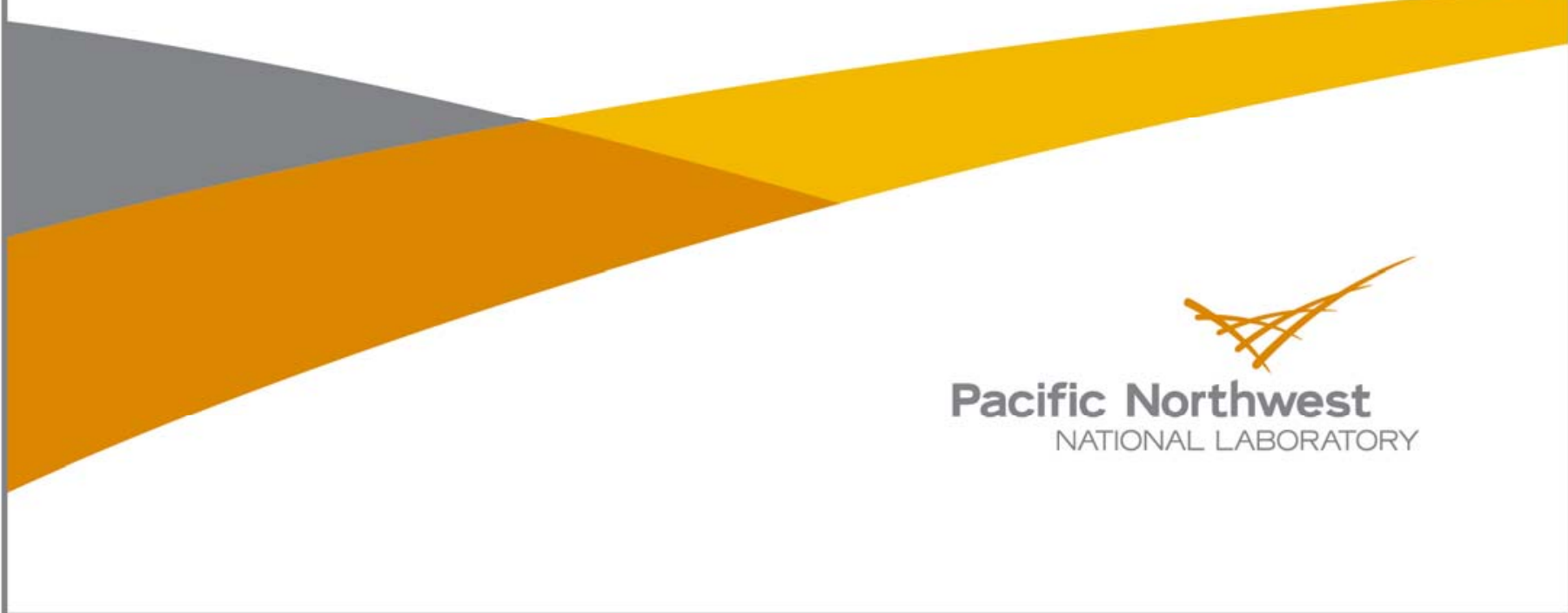




\title{
DISCLAIMER
}

United States Government. Neither the United States Government nor any agency thereof, nor Battelle Memorial Institute, nor any of their employees, makes any warranty, express or implied, or assumes any legal liability or responsibility for the accuracy, completeness, or usefulness of any information, apparatus, product, or process disclosed, or represents that its use would not infringe privately owned rights. Reference herein to any specific commercial product, process, or service by trade name, trademark, manufacturer, or otherwise does not necessarily constitute or imply its endorsement, recommendation, or favoring by the United States Government or any agency thereof, or Battelle Memorial Institute. The views and opinions of authors expressed herein do not necessarily state or reflect those of the United States Government or any agency thereof.

\author{
PACIFIC NORTHWEST NATIONAL LABORATORY \\ operated by \\ BATTELLE \\ for the \\ UNITED STATES DEPARTMENT OF ENERGY \\ under Contract DE-AC05-76RL01830 \\ Printed in the United States of America \\ Available to DOE and DOE contractors from the \\ Office of Scientific and Technical Information, \\ P.O. Box 62, Oak Ridge, TN 37831-0062; \\ ph: (865) 576-8401, fax: (865) 576-5728 \\ email: reports@adonis.osti.gov \\ Available to the public from the National Technical Information Service, \\ U.S. Department of Commerce, 5285 Port Royal Rd., Springfield, VA 22161 \\ ph: (800) 553-6847, fax: (703) 605-6900 \\ email: orders@ntis.fedworld.gov \\ online ordering: http://www.ntis.gov/ordering.htm
}

This document was printed on recycled paper.

$(8 / 00)$ 
PNNL-18337

\section{Energy Efficiency Potential in Existing Commercial Buildings: Review of Selected Recent Studies}

DB Belzer

April 2009

Prepared for

U.S. Department of Energy

under Contract DE-AC05-76RL01830

Pacific Northwest National Laboratory

Richland, Washington 99352 



\section{Summary}

The goal of DOE's Zero-Net Energy Commercial Building Initiative (CBI) is to develop marketable Zero-Net Energy Commercial Buildings, buildings that use cutting-edge efficiency technologies and on-site renewable energy generation to offset their energy use from the electricity grid by 2025. While the impact on commercial energy use in the long term may be substantial from this initiative, over the near term the potential to reduce energy consumption in existing buildings may be more important. The U.S. Department of Energy requested Pacific Northwest National Laboratory to review recent literature as it applied to state and utility efforts to reduce energy use in existing commercial buildings, as a means of helping to define programmatic activities at the federal level. PNNL reviewed six different studies from states all across the U.S. and found that:

- The studies clearly reveal that lighting is the end use that continues to have the largest and most cost-effective energy saving potential in existing commercial buildings. The majority of studies reviewed here were intended to guide utilities and state regulatory agencies with regard to expanding programs to capture a significant fraction of this potential.

- Taken as a group, the studies examined here suggest that improvements in refrigeration systems and components are the second largest source of savings potential.

- The measures related to HVAC generally covered replacing packaged (roof-top) equipment or chiller with more efficient units or installing economizers. With regard to packaged units, the pending federal standards will largely capture this potential.

- With regard to office equipment, the most significant measures considered by a majority of the studies involve power management of computer networks (including night-time shutdown of desktop computers). Current network management systems, that require night-time file backup and automated software upgrades would appear incompatible with such power management activities.

- By and large, little consideration of opaque envelope (roof, wall and foundation) upgrades was included in these studies. Consideration of windows also showed very little potential.

Overall the study indicated that a reasonable range of economic savings potential in existing commercial buildings is between 10 and 20 percent of current energy use. If lighting measures alone are considered, the range of economic savings falls in the range of 3 to 12 percent.

This review also extended to a report on building monitoring and controls and the potential to improve energy efficiency of existing buildings. However, as a whole, the state and utility studies reviewed here placed little emphasis on the potential for this technology. In large part, this likely stems from the complexity in trying to define an incentive program that would promote adoption of such systems. It is estimated that building sensors and controls-excluding those associated with lighting--have the potential of reducing commercial building energy use by an additional 5 to 20 percent. However, these savings are difficult to distinguish with general improved management and operations or commissioning efforts. 


\section{Contents}

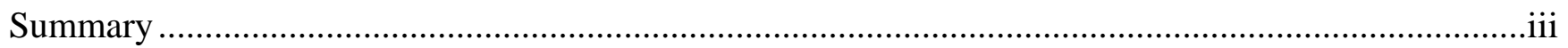

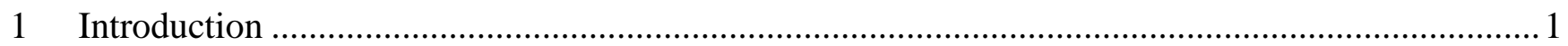

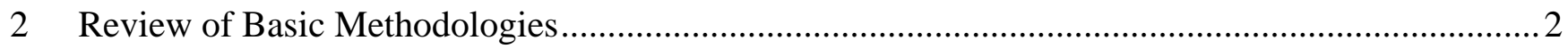

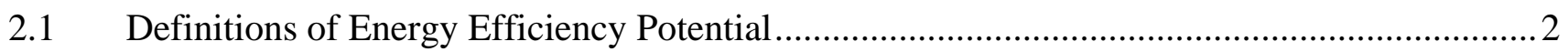

2.2 Criteria for Economic Efficiency.........................................................................................

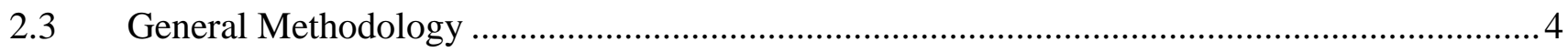

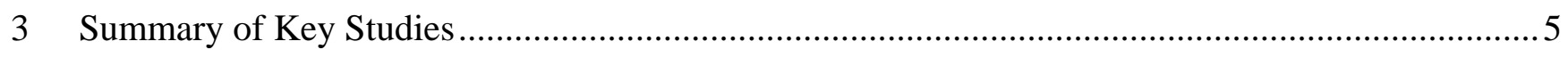

3.1 California Statewide Commercial Sector Study (2002)...........................................................

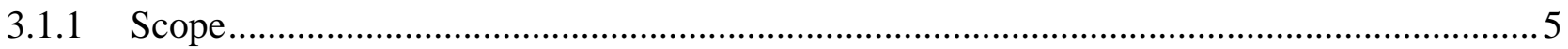

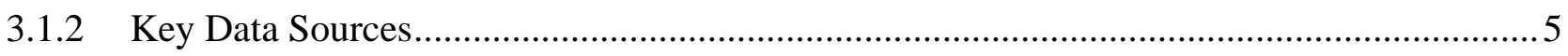

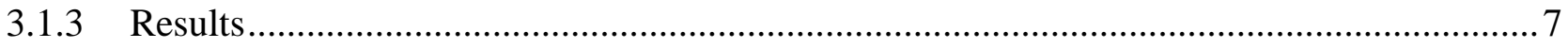

3.2 Connecticut Assessment of Energy Efficiency Potential (2004) ………………........................

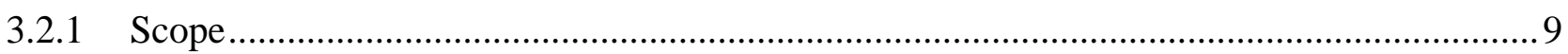

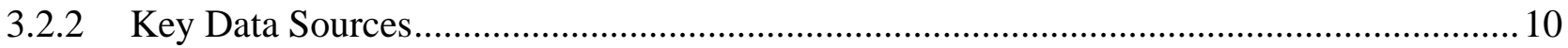

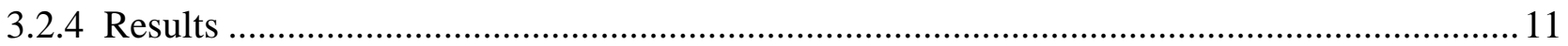

3.3 Northwest Power Planning Council - Fifth Plan (2005) ………………………....................14

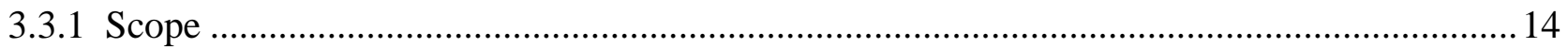

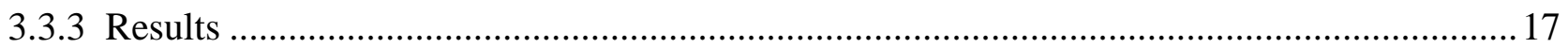

3.4 Vermont Electric Energy Efficiency Study ........................................................................21

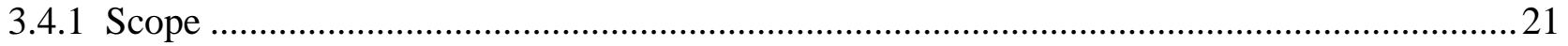

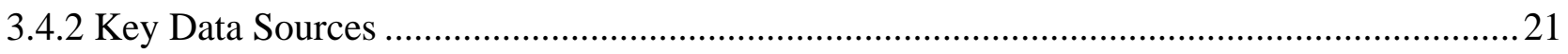

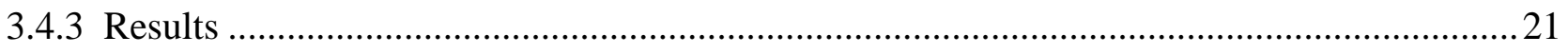

3.5 Colorado DSM Market Potential Assessment (2006) ..................................................................24

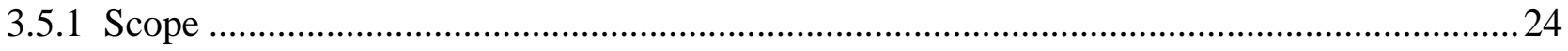

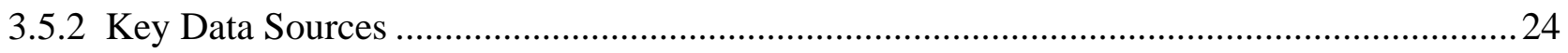

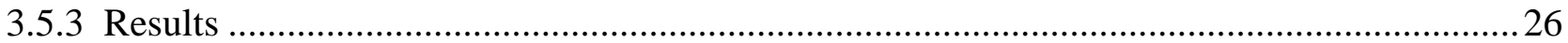

3.6 Commonwealth Edison 2008-2010 Energy Efficiency and Demand Response Plan (2007) ......29

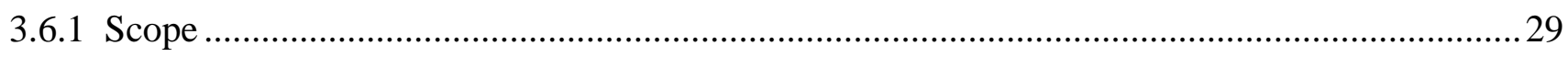

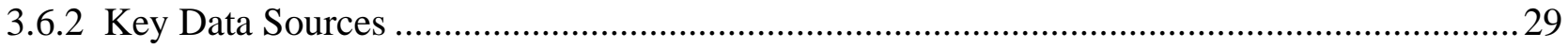

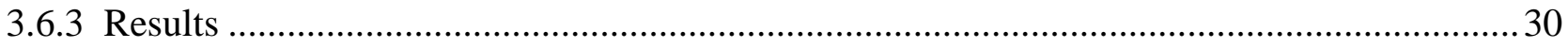




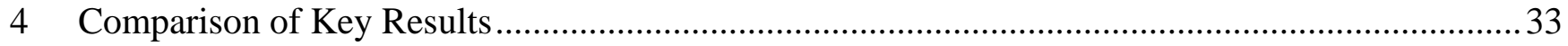

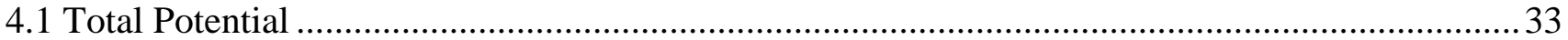

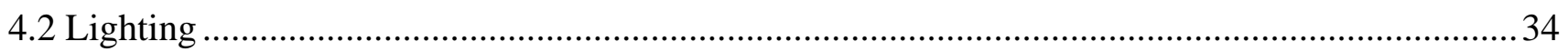

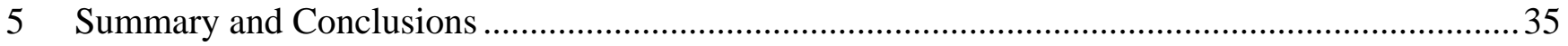

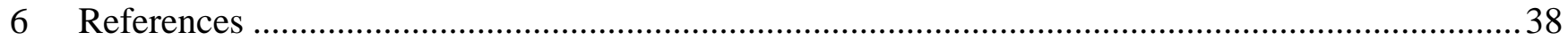

Appendix - Comparison of Linear Fluorescent Cost-Effectiveness Across Studies .............................4 41 


\section{Figures}

Figure 3.1: Percentage Breakdown of Estimated Technical Potential, 2002 California

Statewide Commercial Energy Efficiency Potential Study

Figure 3.2: Commercial Conservation Supply Curve from 2002 California Statewide Energy

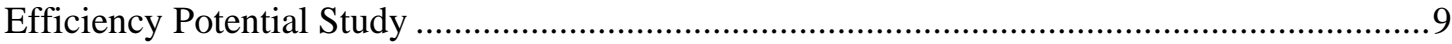

Figure 3.3: Distribution of Cost Effective Achievable Savings - 2004 Connecticut Study ............12

Figure 3.4: Conservation Supply Curve for Existing Commercial Buildings - 2004 Connecticut

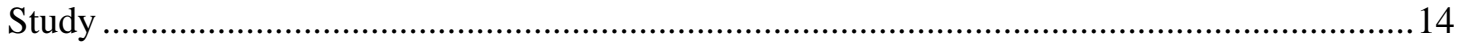

Figure 3.5: Estimated Conservation Supply Curve for Existing Northwest Commercial

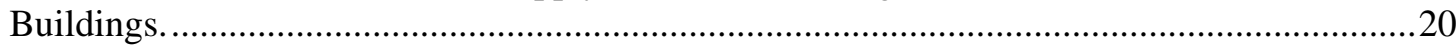

Figure 3.6: Distribution of Cost Effective Achievable Savings - 2005 NWPPC Study.................20

Figure 3.7: Distribution of Cost-Effective Achievable Savings by End Use for Vermont...............23

Figure 3.8: Distribution of Baseline Commercial Electricity Consumption by End Use in Vermont

Figure 3.9: Distribution of Commercial Indoor Lighting Technologies by Floor

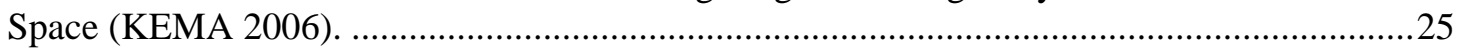

Figure 3.10: Distribution of Linear Fluorescent Fixtures by Efficiency Type..............................26

Figure 3.11: Distribution of Economic Potential by End Use for Xcel Energy (Colorado) ............27 


\section{Tables}

Table 3.1: Summary of Efficient Lighting Equipment Saturation .................................................6

Table 3.2: Aggregated Measure Values for Energy Efficiency Supply Curves...............................8

Table 3.3: Energy Efficiency Potential Compared to Projected 2012 Electricity Use, New and Existing Commercial Buildings - Connecticut................................................................

Table 3.4: Measure Values for Connecticut Conservation Supply Curve - Existing ......................13

Table 3.5: Web Sources for NWPPC Lighting Data................................................................15

Table 3.6: Commercial Sector Lost-Opportunity Measures (NWPPC Fifth Power Plan)...............18

Table 3.7: Commercial Sector Retrofit Measures (NWPPC Fifth Power Plan) .............................18

Table 3.8: Estimated Potential for Existing Commercial Buildings in the Pacific Northwest ........19

Table 3.9: Aggregate Commercial Electricity Potential in Vermont ............................................22

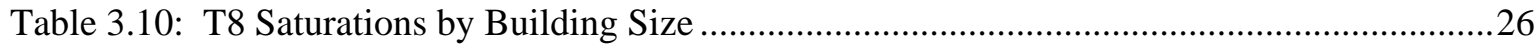

Table 3.11: Lighting Savings for Individual Measures for (KEMA) Colorado Study ...................28

Table 3.12: Values for Saturation for Selected Commercial Efficiency Measures - ComEd

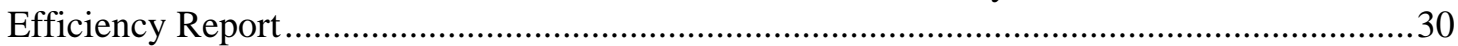

Table 3.13: Legislative Goals for Energy Efficiency and Demand Response for Illinois ...............31

Table 3.14: Types of Measures Passing and Failing Cost-Effectiveness Tests ..............................32

Table 4.1: Comparison of Total Technical and Economic Efficiency Potentials ..........................33

Table 4.2: Energy Savings Potential from Lighting (All Measures)...............................................34 


\section{Introduction}

The goal of DOE's Zero-Net Energy Commercial Building Initiative (CBI) is to develop marketable Zero-Net Energy Commercial Buildings, buildings that use cutting-edge efficiency technologies and renewable energy generation to offset their energy use from the electricity grid by 2025. DOE's Commercial Buildings Program includes research, development, and demonstration of high-performance and green building technologies; and active engagement with significant market actors, design methods, and operational practices. Technology development efforts focus on breakthrough technologies that will be needed to realize exemplary energy performance levels.

While the impact on new construction is obvious, CBI will also impact existing buildings. It is inherently easier to address energy use at point of design and new building construction, than it is in a retrofit or operational and maintenance mode in an existing building. To make significant progress in reducing overall commercial energy consumption over the next several decades, improved energy efficiency will be required in existing buildings. Based upon the projections in the 2008 Annual Energy Outlook (EIA 2008), roughly 60 percent of commercial floor space in 2030 will be in buildings that were built in 2008 or earlier. The United Nations' Intergovernmental Panel on Climate Change found that the largest energy (and carbon) savings potential in 2030 is in existing buildings through retrofit and renovation (IPCC Fourth Assessment Report, Working Group III Report "Mitigation of Climate Change", chapter 6)

This report examines recent state and utility assessments of the energy efficiency potential in existing commercial buildings. The estimates of the magnitude of this potential can help inform policy makers as they balance their program portfolio to address the new and existing buildings market. Six studies are reviewed beginning with a 2002 assessment specifically aimed at commercial buildings in California. Other, more recent studies considered energy efficiency in Connecticut, the Pacific Northwest, Vermont, Colorado, and Illinois. These studies covered residential and industrial efficiency potentials as well as commercial building efficiency, but in all cases, the studies reported sector-specific results. 


\section{Review of Basic Methodologies}

Three concepts are important to the understanding of the energy efficiency potential. First is the definitions of "potential" itself, whether technical, economic, or some other variant. Second is the valuation of that potential, or "total resource cost". Finally, is the comparison between technologies (and relative costs and benefits) of these technologies as they are implemented in the commercial building sector reach that potential.

\subsection{Definitions of Energy Efficiency Potential}

Several approaches have been used to define energy efficiency potential. Most of the reviewed studies developed measures of technical potential, but measures that consider economics and potential market adoption rates differ among these studies. In the California and Colorado studies (Xenergy 2000a, KEMA 2006) performed by Xenergy and KEMA, the development of efficiency measures follows a conventional approach, defining economic potential as a direct subset of technical potential. From economic potential, several other measures are then derived depending upon the nature of energy efficiency programs that may be undertaken by the utility (or utilities). All of these measures are defined in detail below.

As defined by KEMA-Xenergy ${ }^{1}$, Technical Potential refers to the amount of energy savings that would occur with complete (and instantaneous) penetration of all measures in applications where they were deemed technically feasible from an engineering perspective. $^{2}$ Economic Potential includes the technical potential of only those measures that are cost effective when compared to the supply-side alternative or the price of energy. In practice, this selection of measures is not straightforward because there are a number of ways to define the costs of new energy supply.

Most studies include another concept of potential energy savings that takes into account the practical limitations on achieving these savings, often based on prior experience with public or utility programs. In the KEMA-Xenergy studies, Maximum Achievable Potential is defined as the amount of economic potential that could be achieved over time under the most aggressive program scenario possible. Using the KEMA-Xenergy classification, maximum achievable potential is always less than economic potential for several reasons. First, even if rebates and other financial incentives are sufficient to fully offset the higher cost of energy efficient measures, some customers will still not

\footnotetext{
${ }^{1}$ The U.S. energy consulting firm, Xenergy, was acquired as a wholly-owned subsidiary in late 2000 by KEMA — a worldwide energy consulting firm headquartered in the Netherlands. For this report, we will generally refer to this organization as KEMA-Xenergy.

${ }^{2}$ Note that the technical and economic potential are both defined relative to the measures considered in the study and, thus, will not be exactly comparable across the existing studies or a future study that took a more comprehensive look at feasible measures. Thus, for example, envelope measures were given little emphasis in the studies reviewed here, but one can certainly expect that replacing a large fraction of windows in existing buildings with windows that meet the current ASHRAE 90.1 Standard would save a significant amount of energy.
} 
implement those technologies for other reasons such as unfamiliarity or simply higher budget priorities. Second, administration and marketing costs related to utility (or governmental) programs adds to the overall costs of the measures-thus reducing the amount of the potential market that is economic to acquire.

The consulting firm GDS Associates also conducted several energy efficiency potential studies for both states and utilities (GDS Associates and Quantum Consulting 2004, GDS Associates 2006). In these reports, technical potential is defined in the same manner as above; as the "overnight" savings potential from all measures that were deemed technically feasible from an engineering perspective. GDS, however, eschews reporting an overnight economic potential. Rather, it proceeds to estimate maximum achievable potential directly from technical potential. Maximum achievable potential is the potential that can be achieved by a given year, generally eight to ten years in the future. Thus, GDS's definition of maximum achievable potential is less than that used by KEMAXenergy because some measures are assumed to be only undertaken when equipment is normally replaced and that future date might be beyond the scope of the study. Based upon a review of earlier studies and interviews with energy efficiency professionals in a number of utilities, GDS employs a blanket assumption that $80 \%$ of technical potential (after accounting equipment replacement) is the maximum amount of savings that can be achieved from individual measures.

The maximum achievable potential is estimated for each measure that is technically feasible. GDS then applies an economic test to estimate what they term cost-effective achievable savings. The aggregate measure of cost-effective savings includes only those measures that satisfy the economic test chosen (as discussed below).

\subsection{Criteria for Economic Efficiency}

The Total Resource Cost (TRC) test measures the net costs of a demand-side management or efficiency program as a resource option. It is based upon the total costs of the program including both the participants' and the utility's costs. The benefits considered by the test, which are used to compute the net costs, are the avoided supply cost. The avoided supply cost is are the costs associated with avoided new generating capacity, transmission, and distribution that can be attributed to the program's energy savings.

In simplest terms, the total resource cost is constructed by comparing the costs of avoided energy supply (generation, transmission, and distribution in the case of electricity) to the participant's (end-user's) cost of implementing the particular efficiency measure (i.e., investment cost). Both values are discounted over some particular time horizon (e.g., 20 years). Typically, a benefit-cost ratio is used as the TRC metric and is computed as the ratio of the present value of the avoided costs to the present value of the measure cost. Ratios exceeding unity are deemed to be cost effective by this criterion. At the measure level of the TRC calculation, utility or governmental program costs are typically excluded (Xenergy 2002a). 


\subsection{General Methodology}

Most of the studies reviewed in this report follow the same basic approach. A good description of the basic steps is provided by GDS Associates in their 2004 study of efficiency potential for Connecticut (GDS Associates and Quantum Consulting 2004). The steps are:

1. Identify efficiency measures and data sources to be used in the study

2. Determine characteristics of each measure including its incremental cost, energy savings, operations and maintenance savings, useful life, and peak demand impacts.

3. Calculate initial cost-effectiveness screening metrics (e.g., levelized cost per kWh saved and the total resource cost (TRC) benefit-cost ratio. Sort measures from least cost to highest cost

4. Collect baseline and forecasted characteristics of the market, including equipment saturation levels, consumption, and peak demand, by market segment and end use over the forecast period.

5. Integrate measures characteristics and baseline data to produce estimates of cumulative costs and savings across all measures (supply curves).

6. Determine the cumulative technical and maximum achievable potentials using supply curves

7. Incorporate ramp-up schedules to assess the maximum achievable potential over the study's forecast horizon.

The use of energy-efficiency supply curves is a key element in this approach.

Conservation supply curves were initially used in the 1970s as a means of ranking energy conservation investments alongside investments in energy supply. This approach allowed users, usually states or utilities, to assess the least cost approach to meeting energy service demands. The supply curve has the advantage that it provides a clear, easy-to-understand framework for summarizing a variety of complex information about energy-efficiency technologies. However, care must be taken to account for interactions between measures.

In general, most studies have presented supply curves that order the efficiency measures in increasing order of levelized cost per kWh saved. However, measures that are included in the development of total economic potential must satisfy the total resource cost test (or some variant). The total resource cost considers the avoided cost by the utility and so the characteristics of the load reduction (e.g., time of day or season) as they impact daily or seasonal generation costs are considered. Moreover, in the studies reviewed here, the development of the initial estimates of economic potential is made by excluding the utility cost (e.g., program administration and marketing). Thus, the estimates shown in the studies below correspond to only the consumer's investment cost in energy-efficient measures. 


\section{Summary of Key Studies}

Six studies were reviewed are discussed in this section. For each study, the scope, data sources, and findings are discussed. Section 4 provides a comparison of key results.

\subsection{California Statewide Commercial Sector Study (2002³)}

Under the direction of the Pacific Gas and Electric, Xenergy conducted a statewide study of commercial building energy-efficiency potential that was published in mid-2002 (Xenergy 2002a, 2002b).

\subsubsection{Scope}

This study covered the commercial sector served by the state's three largest utilities: Pacific Gas and Electric (PG\&E), Southern California Edison (SCE), and San Diego Gas and Electric (SDG\&E). In 2000, these three utilities accounted for about 80,000 GWh of commercial electricity sales - making up more than $80 \%$ of the estimated statewide commercial sales of 92,000 GWh.

The study examined energy-efficiency potential only in existing commercial buildings, and considered both retrofit and replacement-on-burnout measures. In terms of achievable savings, the study focused on the mid-term, which was defined as the next ten years from the from the baseline year used in the study (2000).

\subsubsection{Key Data Sources}

The key data sources required to develop the estimates of energy-efficiency potential are 1) baseline technology market shares, 2) costs and savings associated with various energy efficiency measures, and 3) the extent to which these energy efficiencies have already been implemented in the building sector (saturations).

\section{Baseline Technology Market Shares}

The baseline data for technology market shares were developed primarily from detailed commercial end use surveys (CEUS) conducted by each of the three utilities. PG\&E conducted on-site surveys of 983 buildings in 1996 and 1997. SCE conducted similar surveys, involving a total of 700 commercial buildings, in 1992 and 1993. SDG\&E conducted an on-site survey of 350 commercial buildings in 1998.

\section{Energy Efficiency Measures, Costs and Savings}

The Xenergy study started with the database of technology costs constructed as part of the 2001 update to California Database for Energy Efficient Resources (DEER) ${ }^{4}$. Energy-efficiency measures savings were developed from a number of sources,

\footnotetext{
${ }^{3}$ Report publication year

${ }^{4}$ The California Database for Energy Efficiency Resources (DEER) was developed by the California Public Utilities Commission to provide well-documented estimates of energy and peak demand savings values, measure costs, and effective useful life within a single data source.
} 
including: 1) standard engineering calculations, 2) the California Conservation Inventory Group (CCIG) Technology Energy Savings Study (NEOS 1994a,b,c), a comprehensive Lawrence Berkeley National Laboratory (LBNL) refrigeration study (Sezgen and Koomey 1995) and recent utility program filings.

\section{Existing Energy-Efficiency Measures Saturations}

For lighting, the saturations of efficient equipment technologies (T8/electronic ballast, compact fluorescent [CFL], and high intensity discharge [HID]) were initially developed from the PG\&E CEUS and SDG\&E evaluation databases. Because these data were as much as five years old, Xenergy made adjustments to the saturation levels to account for "naturally occurring and program-influenced installations" that may have occurred since the initial data were collected. Table 3.1 reproduces a table in the Xenergy report dealing with lighting equipment saturations.

\section{Table 3.1: Summary of Efficient Lighting Equipment Saturation}

\begin{tabular}{|l|l|c|c|c|}
\hline \multirow{2}{*}{ End Use } & \multirow{2}{*}{$\begin{array}{l}\text { Equipment } \\
\text { Type }\end{array}$} & \multicolumn{3}{|c|}{ Saturation (fraction of floor space) } \\
\cline { 2 - 5 } & Initial & Final & Small -Final \\
\hline \multirow{4}{*}{ Indoor Lighting } & 4 Foot T8 & 0.371 & 0.552 & 0.250 \\
\cline { 2 - 5 } & 8 Foot T8 & 0.126 & 0.336 & 0.112 \\
\cline { 2 - 5 } & CFLs & 0.189 & 0.593 & 0.407 \\
\cline { 2 - 5 } & HIDs & 0.372 & 0.424 & 0.219 \\
\hline \multirow{2}{*}{$\begin{array}{l}\text { Outdoor } \\
\text { Lighting }\end{array}$} & T8s & 0.185 & 0.185 & 0.054 \\
\cline { 2 - 5 } & HIDs & 0.830 & 0.830 & 0.756 \\
\hline
\end{tabular}

Source: Table A-9 (Xenergy-KEMA 2002).

The final column in Table 3.1 shows the saturation rates for "small customers." Unfortunately, there is no specific reference to the amount of energy use (or floor space) that defines a small customer. Nevertheless, we can speculate that the key lighting measure, T8 with electronic ballast, had likely penetrated over 40 percent of the floor space in California by 2002, if the data and assumptions used by Xenergy were accurate.

The PG\&E CEUS provided information on occupancy sensors for lighting as of 1997. Occupancy sensors were estimated to have about $5 \%$ overall saturation, concentrated primarily in office buildings.

As a result of the electricity crisis in California in 2000 and 2001, the CEC's emergency equipment efficiencies for new packaged air conditioners and chillers were increased. As a result, the saturation rates for units exceeding these new, higher efficiency standards were set equal to zero. For small DX units, the new California standard was changed from an Energy Efficiency Ratio (EER) of 8.9 to 10.3, consistent with the 1999 ASHRAE 90.1 Standard (ASHRAE/IESNA 1999).

The PG\&E study provided information on the usage of variable speed drive (VSD) motors in building ventilation systems. As used in the 2002 study, the saturation of this 
technology was estimated to be $3 \%$ in the 5 -hp range, $9 \%$ in the 15 -hp range, and $39 \%$ in the 40-hp range.

For refrigeration, the study relied on a national study of refrigeration electricity use and efficiency measures prepared by LBNL (Sezgen and Koomey 1995). The efficiency measures were applied only to grocery stores.

\subsubsection{Results}

Xenergy concluded that within the service areas of the three major California utilities, the technical potential for electricity savings as of the year 2000 was just under 15,000 GWh $(14,731 \mathrm{GWh})$ or about $18 \%$ of base energy usage. Economic potential was estimated to be $10,627 \mathrm{GWh}$, or about $13 \%$ of base energy usage.

Figure 3.1 provides a breakdown of technical potential by end use. Technical potential from lighting comprises half of the total potential, followed by cooling and refrigeration.

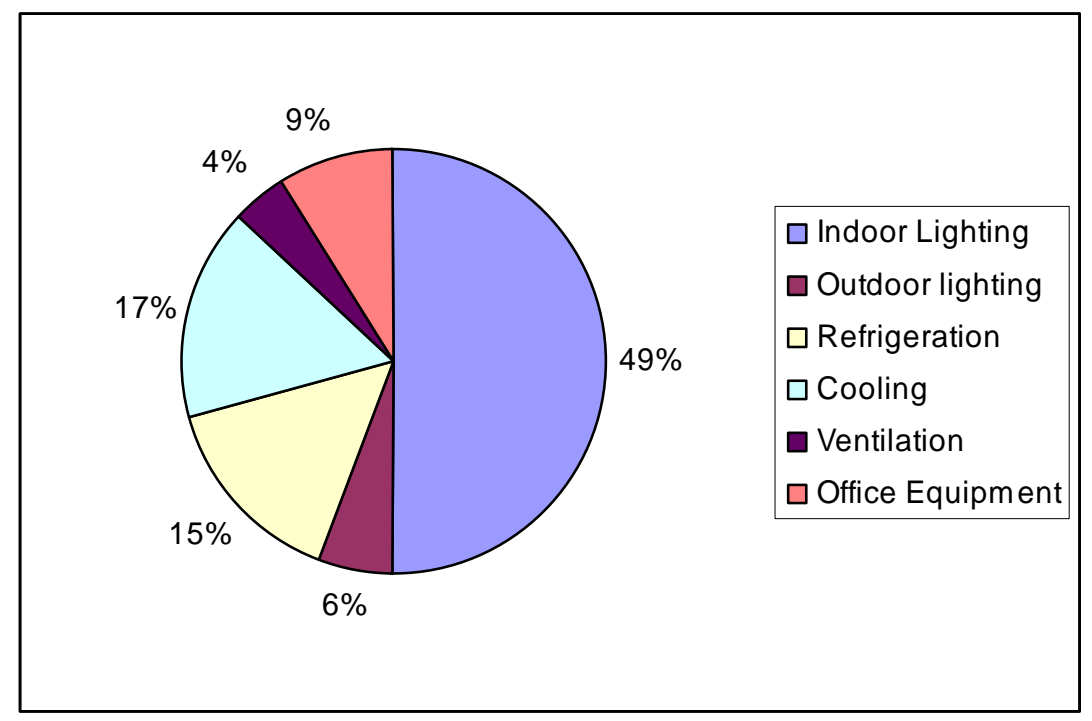

Figure 3.1: Percentage Breakdown of Estimated Technical Potential, 2002 California Statewide Commercial Energy Efficiency Potential Study

Table 3.2 shows savings and costs on a measure-by-measure basis (aggregated across the three utilities). The table suggests that the criterion for economic potential, in terms of levelized cost per kWh saved, is just under $\$ 0.09$ per $\mathrm{kWh}$. Measures in the bottom shaded portion of the table that exceed this value were non-economic in terms of this study. The measure with the largest economic potential in this category was perimeter dimming. Given the costs of dimming ballasts, controls, and installation, Xenergy estimated that the levelized cost of this measure would be $\$ 0.25$ for every kWh saved. 
Table 3.2: Aggregated Measure Values for Energy Efficiency Supply Curves

\begin{tabular}{|c|c|c|c|c|}
\hline Measure & $\begin{array}{c}\text { GWh } \\
\text { Savings }\end{array}$ & $\begin{array}{c}\text { Cumulative } \\
\text { GWh } \\
\text { Savings }\end{array}$ & $\begin{array}{c}\text { Levelized } \\
\text { Energy } \\
\text { Cost } \\
\text { (\$/kWh) }\end{array}$ & $\begin{array}{l}\text { Percent } \\
\text { Savings }\end{array}$ \\
\hline $\begin{array}{l}\text { T8/Electronic. } \\
\text { Ballast/Reflector }\end{array}$ & 1,010 & 1,010 & $\$ 0.007$ & $1.68 \%$ \\
\hline Refrigeration Misc. & 45 & 1,054 & $\$ 0.007$ & $0.08 \%$ \\
\hline Refrigeration Controls & 458 & 1,512 & $\$ 0.017$ & $0.76 \%$ \\
\hline High Efficiency. Chiller & 478 & 1,990 & $\$ 0.017$ & $0.80 \%$ \\
\hline Refrigeration Covers & 350 & 2,340 & $\$ 0.021$ & $0.58 \%$ \\
\hline $\begin{array}{l}\text { Programmable } \\
\text { Thermostat }\end{array}$ & 277 & 2,616 & $\$ 0.022$ & $0.46 \%$ \\
\hline CFL & 724 & 3,340 & $\$ 0.025$ & $1.21 \%$ \\
\hline Exterior Lighting Controls & 236 & 3,576 & $\$ 0.026$ & $0.39 \%$ \\
\hline $\begin{array}{l}\text { Refrigeration } \\
\text { Compressors/Motors }\end{array}$ & 1,222 & 4,798 & $\$ 0.032$ & $2.04 \%$ \\
\hline Ventilation VSD & 453 & 5,251 & $\$ 0.034$ & $0.76 \%$ \\
\hline Occupancy. Sensor & 1,104 & 6,355 & $\$ 0.048$ & $1.84 \%$ \\
\hline Exterior HPS lamps & 319 & 6,674 & $\$ 0.052$ & $0.53 \%$ \\
\hline T8/Elec. Ballast & 2,539 & 9,213 & $\$ 0.059$ & $4.23 \%$ \\
\hline High Eff. DX & 445 & 9,658 & $\$ 0.066$ & $0.74 \%$ \\
\hline HE Ventilation. Motor & 156 & 9,814 & $\$ 0.071$ & $0.26 \%$ \\
\hline $\begin{array}{l}\text { Refrigeration } \\
\text { Commissioning. }\end{array}$ & 112 & 9,927 & $\$ 0.071$ & $0.19 \%$ \\
\hline Office Eq. Power Mgmt & 1,019 & 10,945 & $\$ 0.090$ & $1.70 \%$ \\
\hline Energy Manage. System & 227 & 11,173 & $\$ 0.097$ & $0.38 \%$ \\
\hline Window Film & 224 & 11,397 & $\$ 0.110$ & $0.37 \%$ \\
\hline Halogen & 295 & 11,692 & $\$ 0.136$ & $0.49 \%$ \\
\hline Chiller Pumps & 110 & 11,802 & $\$ 0.148$ & $0.18 \%$ \\
\hline Cooling Tune-ups & 308 & 12,110 & $\$ 0.225$ & $0.51 \%$ \\
\hline Cool Roof & 193 & 12,304 & $\$ 0.238$ & $0.32 \%$ \\
\hline Perimeter Dimming & 1,696 & 14,000 & $\$ 0.250$ & $2.83 \%$ \\
\hline Metal Halide & 273 & 14,273 & $\$ 0.265$ & $0.46 \%$ \\
\hline Pre-Cooler & 170 & 14,444 & $\$ 0.326$ & $0.28 \%$ \\
\hline $\begin{array}{l}\text { Office Equipment Night } \\
\text { Shutdown. }\end{array}$ & 113 & 14,556 & $\$ 2.031$ & $0.19 \%$ \\
\hline LCD Monitor & 165 & 14,721 & $\$ 5.976$ & $0.28 \%$ \\
\hline
\end{tabular}

Source: Table 6-3 (Xenergy 2002b)

Figure 3.2 shows the conservation supply curve based upon these data points. The last two measures in Table 3.2 were not included in the curve, because their levelized costs were significantly higher than all of the other measures considered. 


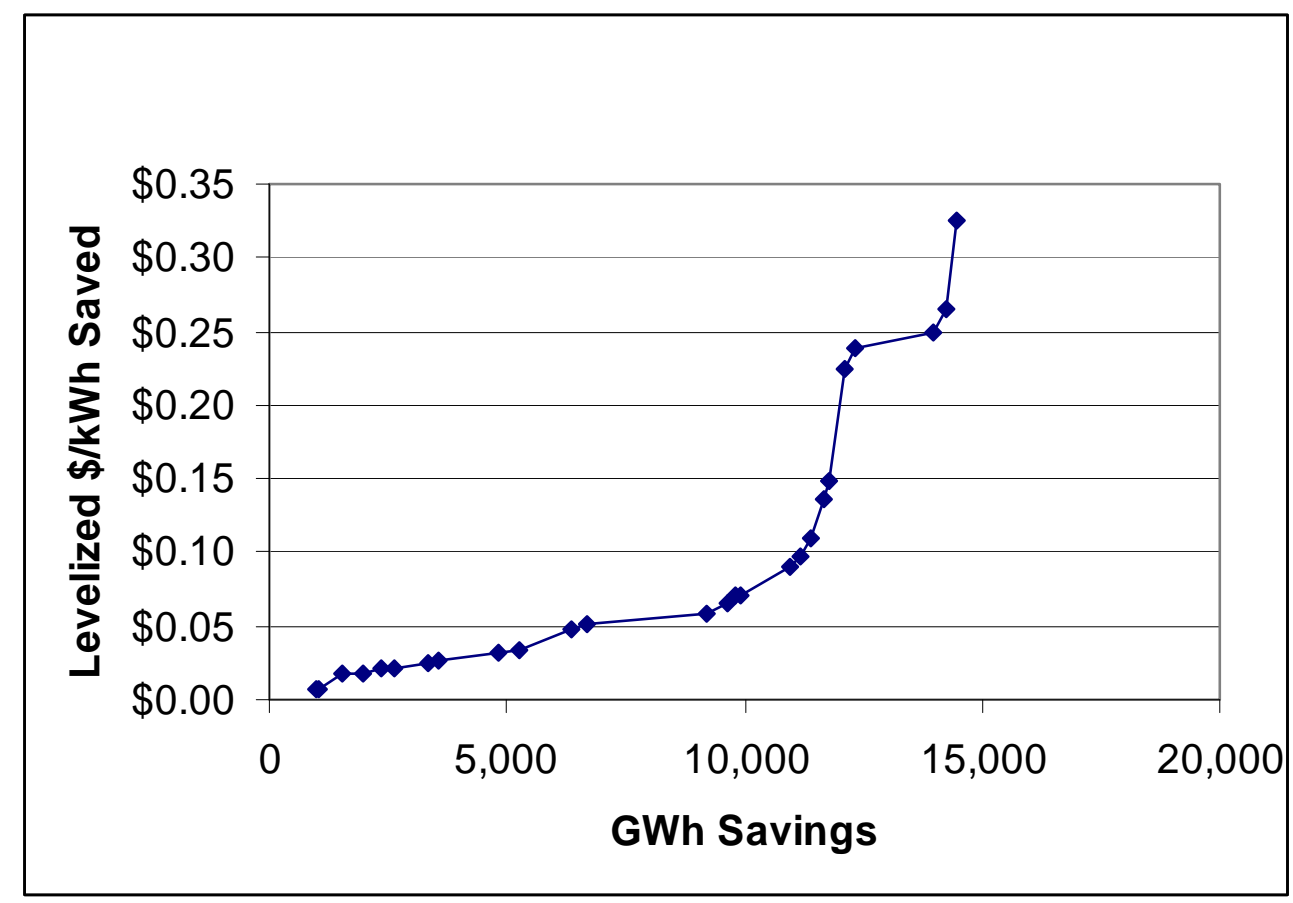

Figure 3.2: Commercial Conservation Supply Curve from 2002 California Statewide Energy Efficiency Potential Study

\subsection{Connecticut Assessment of Energy Efficiency Potential (2004)}

In 2004, GDS Associates and Quantum Consulting completed an assessment of energy efficiency potential for the Connecticut Energy Conservation Management Board (GDS Associates and Quantum Consulting 2004).

\subsubsection{Scope}

This study examined energy-efficiency potential in the geographic regions served by the United Illuminating and Connecticut Light and Power Company. The study objective was to estimate the "maximum achievable cost effective potential" for energy efficiency over the ten-year period from 2003 through 2012. The study distinguished measures for both existing and new commercial construction. The study considered efficiency potential for the residential, commercial, and industrial sectors. Three geographic areas were considered:

- Connecticut statewide

- 52 towns in the electricity supply “constrained” area of southwest Connecticut

- 16 critical constrained-area towns in the southwest Connecticut (NorwalkStamford area)

For this study, only the statewide results for the commercial sector are examined. To the extent possible, we examine only the measures that pertain to existing buildings. 


\subsubsection{Key Data Sources}

The Connecticut study relied upon a wide variety of existing studies conducted throughout the U.S. on the potential savings and penetration of energy-efficiency measures. Over 300 individual measures were analyzed in the study (for residential, commercial, and industrial sectors). For the commercial sector, 104 efficiency measures were included in the study.

\section{Baseline Technology Market Shares}

The GDS/Quantum report indicates that over 200 data sources (reports/databases) were consulted in the development of the study. Twenty-one studies related to either the commercial or industrial sectors. The authors indicate four studies under the heading "Connecticut Saturation Studies." The four saturation studies included the 1997 Residential Energy Consumption Survey (RECS), the 1999 Commercial Building Energy Consumption Survey (CBECS), as well as two appliance saturation reports dealing strictly with the residential sector. Some 50 electronic files were supplied by the two major Connecticut utilities cited above. Unfortunately, no specific reference could be found in the study as the source of saturation rates for key commercial energy efficiency measures such as T8s or high-efficiency DX equipment. With respect to lighting, the most relevant study appears to have been a 1997 baseline study conducted in 1997 (New England Commercial and Industrial Lighting Market Transformation and Baseline Study conducted by Easton Consulting (1997) for the New England Electric System (NEES) and several other funding organizations].

\section{Energy Efficiency Measures Costs and Savings}

The study used a variety of sources to develop estimates of efficiency measure costs and savings. For each specific measure, Appendix $\mathrm{C}$ in the report lists the sources for the measure savings (although with no specific mention of the baseline technology), measure cost, and measure life. For upgrades involving electronic ballasts for interior lighting, the primary source for savings was the Rensselaer Lighting Research Center, and for costs, the California Statewide Commercial Sector study (discussed in the previous section). For refrigeration, the California study provided most of the energy savings estimates. For costs associated with refrigeration improvements, the study relied on the California study as well as "cost effectiveness models" that had been prepared for the states of Wisconsin and Maine. For centrifugal chillers, the savings estimates relied primarily on a 1999 study (Northeast Utilities System 1999 Express Service Program Impact Evaluation Final Report). Cost estimates were based upon information from the Trane Company and a website maintained by a western wholesale electric power supplier. ${ }^{5}$. Chiller tune-up savings and cost relied on the 2002 California statewide study. Finally, for DX (packaged) cooling equipment, most of the cost and savings estimates were taken from a 2000 ACEEE study ("Per Unit Incremental Costs and Savings of High Efficiency Packaged Commercial A/C”).

\footnotetext{
${ }^{5}$ The Tri-State Generation and Transmission Association (serving portions of Colorado, Nebraska, New Mexico and Wyoming) website:,tristate.apogee.net/cool/cmnch.asp, accessed March 5, 2009
} 


\section{Existing Energy-Efficient Measure Saturations}

No specific tables in the report appear to provide estimates as to what degree the efficiency measures may had already been installed in the commercial sector. In reference to the supply curve for the commercial sector, the authors state parenthetically that the savings from Super T8 lighting fixtures "includes the replacement of the estimated $30 \%$ of the existing market that has not yet converted to standard T8 fixtures ...”

\subsubsection{Results}

The study is quite optimistic with regard to the magnitude and cost effectiveness of the efficiency potential for the Connecticut commercial sector over the period from 2003 through 2012. According to the study, replacement of lighting systems with more efficient fixtures, lamps, ballasts, and improved controls can save up to 50 percent of lighting energy use. For retrofits involving Super T8's, the payback period was estimated to be typically less than 2 years. More efficient fans, chillers, and packaged air conditioning systems can reduce overall energy consumption between 14 and 30 percent, with a payback of 1.5 to 7 years. The study claimed that energy-efficient office equipment can reduce total (italics added) electricity consumption by 20 to 50 percent in office buildings at minimal cost.

Table 3.3 summarizes the amount of commercial sector efficiency savings with respect to the projected commercial sales in Connecticut $(14,591 \mathrm{GWh})$. The first measures relate to technical (row 1) and cost-effective savings (row 2), based upon an "overnight" definition of potential. The "Maximum Achievable" (row 3) savings (2,524 GWh) is lower as it reflects reductions from equipment turnover (e.g., not all chillers will be normally replaced by 2012), and a blanket assumption that maximum penetration of any technology is $80 \%$. The final row "Cost-Effective Maximum Achievable” reflects a subset of measures from row 3 that are cost effective based upon an "avoided cost" criterion.

Table 3.3: Energy Efficiency Potential Compared to Projected 2012 Electricity Use, New and Existing Commercial Buildings - Connecticut

\begin{tabular}{|l|c|c|}
\hline \multicolumn{1}{|c|}{ Type of Potential } & 2012 Savings (GWh) & $\begin{array}{c}\text { Percent of GWh Sales } \\
\text { (2012) }\end{array}$ \\
\hline Technical & 3,703 & $25.3 \%$ \\
\hline Cost- Effective Technical & 3,063 & $21.0 \%$ \\
\hline Maximum Achievable & 2,524 & $17.3 \%$ \\
\hline $\begin{array}{l}\text { Cost-Effective Maximum } \\
\text { Achievable }\end{array}$ & 2,088 & $14.3 \%$ \\
\hline
\end{tabular}

Source: Table 6-2 and first table in Appendix C (GDS Associates and Quantum Consulting 2004).

Figure 3.3 is essentially reproduced from the report. This figure shows the distribution of cost effective (maximum achievable) savings by end use. 


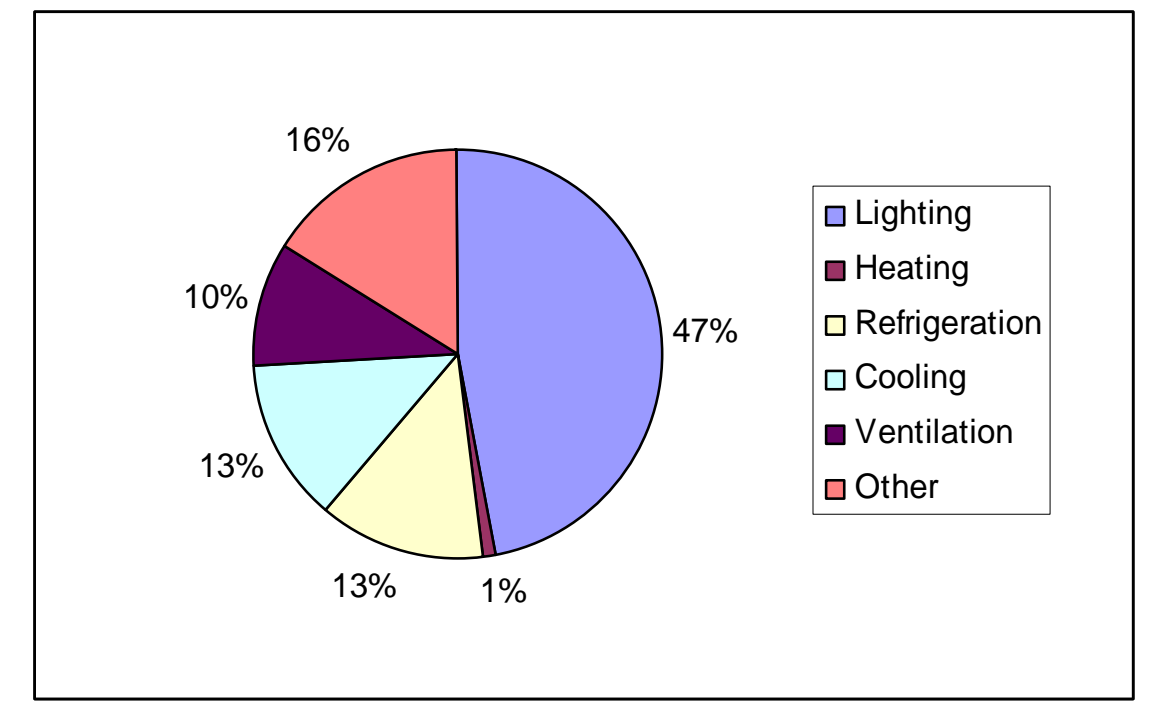

Figure 3.3: Distribution of Cost Effective Achievable Savings - 2004 Connecticut Study

Table 3.4 lists the energy-efficiency measures for existing commercial buildings in order of cost effectiveness. Based upon several tables presented in the appendices of the Connecticut report, existing buildings account for 80 to 90 percent of the total potential (by 2012).

The shaded area at the bottom of the table includes those measures that were not determined as cost effective as defined by the report. Some questions are raised by several entries in the various tables in the report. In particular, the table listing all achievable measures includes a measure that replaces a conventional 4-foot fluorescent fixture on burnout with a T8/electronic ballast and reflector (measure 17 toward the bottom of Table 3.4 below). This particular measure is not included in the study's table, which lists only cost-effective measures. However, the levelized cost of this measure is less than that of the next measure (early replacement of a centrifugal chiller). Thus, it is unclear whether this particular measure competes directly with replacement lighting systems without reflectors or whether some other factor prevented its inclusion from being cost effective (albeit only marginally so with a levelized cost greater than $\$ 0.10$ per kWh saved). 
Table 3.4: Measure Values for Connecticut Conservation Supply Curve - Existing

\begin{tabular}{|c|c|c|c|c|}
\hline Measure \# & Measure Name & $\begin{array}{l}\text { Maximum } \\
\text { Achievable } \\
\text { Savings }\end{array}$ & $\begin{array}{c}\text { Cumulative } \\
\text { Savings }\end{array}$ & $\begin{array}{c}\text { Levelized } \\
\text { Cost } \\
\text { (\$/kWh) }\end{array}$ \\
\hline 99 & Nighttime shutdown - desktop & 121 & 121 & $\$ 0.001$ \\
\hline 100 & Power Management Enabling & 119 & 240 & $\$ 0.002$ \\
\hline 79 & Night covers for display cases - freezers & 9 & 249 & $\$ 0.005$ \\
\hline 61 & Demand defrost electric - freezers & 17 & 266 & $\$ 0.006$ \\
\hline 89 & Fan motor, 15 hp, 1800 rpm, 92.4\% & 23 & 289 & $\$ 0.006$ \\
\hline 71 & Vending machines & 16 & 305 & $\$ 0.007$ \\
\hline 98 & Nightime shutdown - Laptop & 56 & 361 & $\$ 0.007$ \\
\hline 56 & Prog. Thermostat & 14 & 375 & $\$ 0.008$ \\
\hline 78 & Night covers for display cases - refrigerators & 11 & 386 & $\$ 0.010$ \\
\hline 60 & Demand defrost electric - refrig & 20 & 406 & $\$ 0.013$ \\
\hline 88 & HE ice maker & 4 & 410 & $\$ 0.014$ \\
\hline 5 & LED exit signs & 9 & 419 & $\$ 0.015$ \\
\hline 30 & LED signage & 28 & 447 & $\$ 0.015$ \\
\hline 2 & 250 Watt Metal Halide & 7 & 454 & $\$ 0.015$ \\
\hline 25 & ROB 2L4'T8, 1EB, outdoor & 6 & 460 & $\$ 0.019$ \\
\hline 77 & Efficient compressor motor retrofit - freezer & 18 & 478 & $\$ 0.019$ \\
\hline 21 & ROB 4L4' Super T8, 1EB, & 159 & 637 & $\$ 0.020$ \\
\hline 21.5 & RET 4L4' Super T8, 1EB, Early replace & 219 & 856 & $\$ 0.021$ \\
\hline 4 & CFL - hard wired & 318 & 1,174 & $\$ 0.021$ \\
\hline 57 & Economizer, Comparative Enthalpy - Chiller & 25 & 1,199 & $\$ 0.023$ \\
\hline 85 & Walk-in cooler fan control & 11 & 1,210 & $\$ 0.023$ \\
\hline 57 & Economizer, Comparative Enthalpy - Chiller & 97 & 1,307 & $\$ 0.024$ \\
\hline 64 & High Efficiency ice maker & 6 & 1,313 & $\$ 0.027$ \\
\hline 92 & Variable speed drive control, $15 \mathrm{HP}$ & 174 & 1,487 & $\$ 0.030$ \\
\hline 69 & High efficiency fan motors - freezer & 10 & 1,497 & $\$ 0.032$ \\
\hline 96 & Hydronic Heating Pump & 19 & 1,516 & $\$ 0.033$ \\
\hline 70 & Vender miser & 34 & 1,550 & $\$ 0.034$ \\
\hline 84 & Walk-in cooler economizer & 12 & 1,562 & $\$ 0.035$ \\
\hline 76 & Efficient compressor motor retrofit - refrig & 21 & 1,583 & $\$ 0.038$ \\
\hline 41 & Chiller tune up/Diagnostics 500 ton & 2 & 1,585 & $\$ 0.041$ \\
\hline 24 & Outdoor lighting controls & 11 & 1,596 & $\$ 0.043$ \\
\hline 102 & Dry type transformers & 4 & 1,600 & $\$ 0.049$ \\
\hline 8 & Occupancy sensor & 69 & 1,669 & $\$ 0.050$ \\
\hline 50 & Packaged AC 7.5 tone, Tier 2 & 6 & 1,675 & $\$ 0.055$ \\
\hline 36 & Centrifugal Chiller, 0.51 kW/ton & 7 & 1,682 & $\$ 0.062$ \\
\hline 31 & $5 \%$ More efficient lighting design & 11 & 1,693 & $\$ 0.062$ \\
\hline 31.5 & $10 \%$ More efficient lighting design & 21 & 1,714 & $\$ 0.063$ \\
\hline 68 & High efficiency fan motors - refrig & 9 & 1,723 & $\$ 0.064$ \\
\hline 86 & Walk-in cooler door heater control & 39 & 1,762 & $\$ 0.065$ \\
\hline 11 & Pulse start HID & 14 & 1,776 & $\$ 0.074$ \\
\hline 13 & Ret 4L4' HO T1, 1EB, (repl 450 Metal halide) & 58 & 1,834 & $\$ 0.075$ \\
\hline 50.5 & Packaged AC & 18 & 1,852 & $\$ 0.086$ \\
\hline 55 & EMS - chiller & 8 & 1,860 & $\$ 0.103$ \\
\hline 17 & ROB 2L4 Super T8, 1 EB, Reflector & 159.2 & 2,019 & $\$ 0.104$ \\
\hline 37 & Centrifugal Chiller, 0.51 kW/ton, Early Rep & 4 & 2,023 & $\$ 0.116$ \\
\hline 9 & Daylight Dimming & 116 & 2,139 & $\$ 0.126$ \\
\hline 55 & EMS - chiller & 8 & 2,147 & $\$ 0.129$ \\
\hline 81 & Refrigeration commissioning - freezers & 7.2 & 2,154 & $\$ 0.141$ \\
\hline 46 & DX Tune Up & 24 & 2,178 & $\$ 0.147$ \\
\hline 42 & Cooling circulation pumps - VSD & 5.6 & 2,184 & $\$ 0.195$ \\
\hline 80 & Refrigeration commissioning - refrig & 8.8 & 2,193 & $\$ 0.279$ \\
\hline 82 & Strip curtains for walk-ins - refrig & 1.6 & 2,194 & $\$ 0.296$ \\
\hline 59 & Compressor VSD retrofit - freezer & 11.2 & 2,206 & $\$ 0.854$ \\
\hline \multirow[t]{2}{*}{97} & External hardware control - office equipment & 40.8 & 2,246 & $\$ 1.050$ \\
\hline & Other & 108 & 2,354 & $>\$ 1.50$ \\
\hline
\end{tabular}


Figure 3.4 shows the conservation supply based on the values shown in Table 3.4. (In a similar manner as for the previous supply curve, those measures with very high levelized costs have been omitted from the graph.) The three long line segments, beginning at a cumulative savings of about $500 \mathrm{GWh}$, are all related to lighting measures. The first two segments consider both replacement and retrofits of lighting systems to T8/electronic ballast combinations. The third measure involves use of hardwired CFLs to replace incandescent lamps. The next single largest savings (at a cost of about $\$ 0.03 / \mathrm{kWh}$ ) relates to the use of variable-speed-drive motors for ventilation applications.

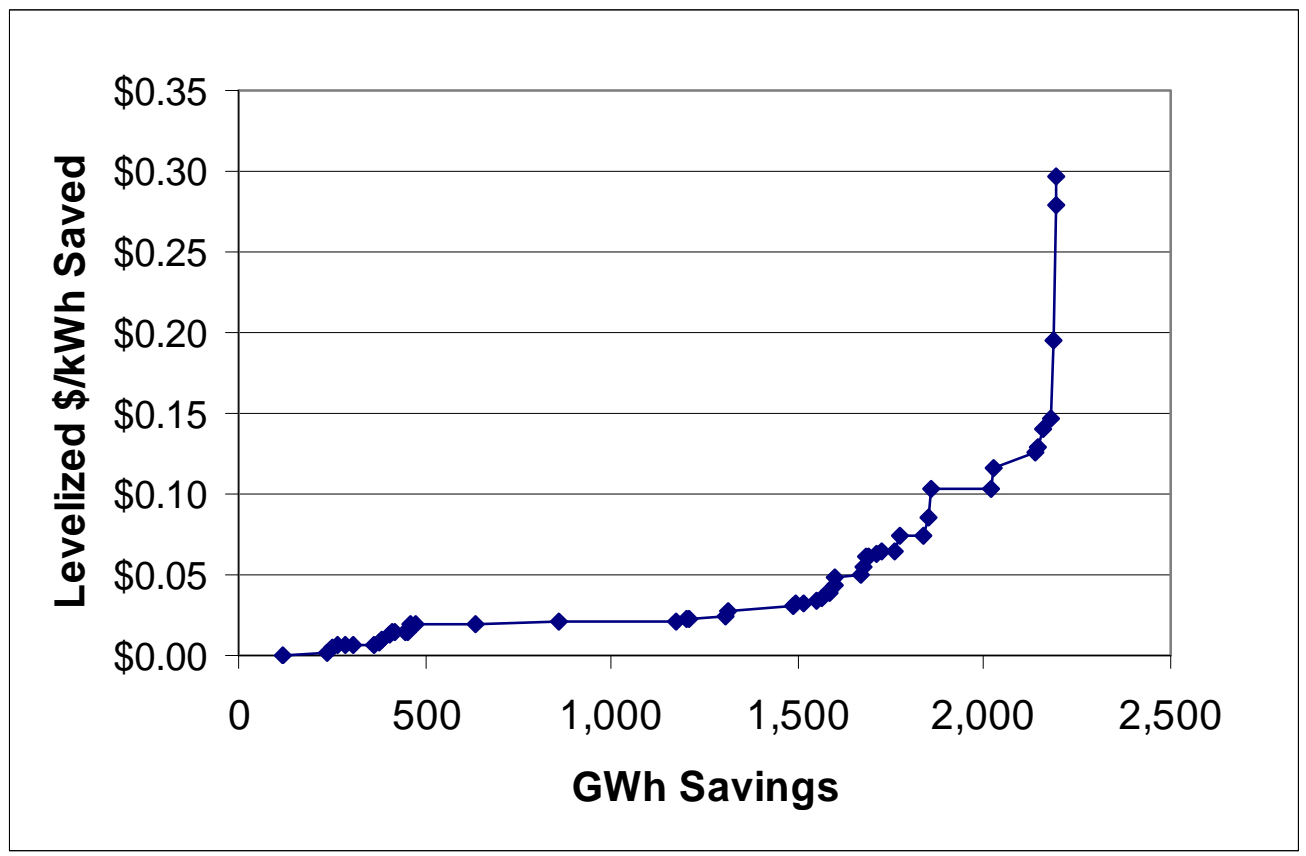

Figure 3.4: Conservation Supply Curve for Existing Commercial Buildings - 2004 Connecticut Study

\subsection{Northwest Power Planning Council - Fifth Plan (2005)}

\subsubsection{Scope}

Comprehensive estimates of energy conservation potential for the Pacific Northwest are made periodically by the Northwest Power Planning Council (NWPPC) The region considered by the NWPCC includes the three states of Washington, Oregon, and Idaho, as well as western Montana. The most recent assessment, The Fifth Northwest Power and Conservation Plan (Fifth Plan), was published in 2005 (NWPPC 2005).

The metric for electric sales used by NWPPC is average megawatts (MWa) and we will use that metric in the following discussion. The total electricity conservation resource 
estimated by NWPPC in 2005 over the next 20 years was estimated to be 3,900 average megawatts. Using a medium case forecast of power market prices in the Pacific Northwest over this two-decade horizon indicated that about 2,800 average megawatts would be cost effective. At this level of savings, the average levelized cost was estimated to be about 2.4 cents per kilowatt-hour. NWPPC considered potential from both new and existing buildings.

In 2000, the commercial sector in this region consumed just over 5,200 average megawatts of electricity. The council estimated that about $88 \%$ of that electricity was used in buildings, with the remainder used in infrastructure such as water and sanitary services, street and highway lighting, traffic signals, communication, and other nonbuilding applications. Under the Fifth Plan, commercial electricity consumption is expected to grow about 1,800 average megawatts by 2025, to a level of about 7,000 average megawatts in that year.

\subsubsection{Key Data Sources}

The report evaluated about 100 measures for possible inclusion in the electricity conservation supply curve. Neither the main report nor the appendices of the Fifth Plan contain specific references and sources. Accompanying the plan on the NWPPC website is a downloadable zip file that contains over 40 spreadsheets that contain the data and methodology for developing the conservation (energy-efficiency) potential estimates. We only made a cursory effort to evaluate some of the key data sources

\section{Energy Efficiency Measures Costs and Savings}

With regard to efficiency measures costs and savings, we took a particular interest in lighting, because lighting continues to be the end use with the largest energy saving potential. For example, Table 3.5 presents a listing of data sources for costs of retrofit lighting upgrades.

Table 3.5: Web Sources for NWPPC Lighting Data

Lamp Ballast \& Fixture Cost Sources
http://www.goodmart.com/default.aspx?section=2
http://www.hidirect.com/
http://www.topbulb.com/
Http://www.atlaslightingsupply.com
https://secure.tcinternet.net/buylighting/cart/

For lighting, the methodology used by NWPPC to assess savings potential appears to involve the use of lighting power densities (LPD) for particular building types. Several commercial building surveys in the Northwest have developed estimates of the LPD in existing building. LPD is convenient in that the lighting requirements of commercial energy codes are typically specified in these terms. ${ }^{6}$

\footnotetext{
${ }^{6}$ The origins of the LPDs in codes in terms of various lighting technologies and other assumptions may be found in article ("Understanding and Applying Evolving Commercial Lighting Energy Codes and
} 


\section{Existing Energy-Efficient Measure Saturations}

The NWPPC staff attempted to calibrate a mix of historical and projected shares of various lighting technologies to match the LPD data (and assumed improvements). Exhibit 3.1, taken from one of the lighting documentation spreadsheets used in the Fifth Plan, provides a flavor of this calibration. For example, a number of lighting design sources were consulted to develop estimates of target improvement in LPDs. The fourth paragraph in Exhibit 3.1 provides a brief, general description of how the calibration of LPD and technology information was undertaken.

\section{Exhibit 3.1. General Description of the Use of LPDs for Existing Building Lighting Retrofit Potential - NWPPC Fifth Plan}

LPD savings estimates come from CBSA data on 1995-2001 vintage stock. Target LPD levels are based on available technology and accepted lighting design practice. Several design sources were considered including new building institute, IES, Jim Benya and others. Nine measures are selected to represent the technologies applicable in existing buildings. Measures include moving to High Performance T8 (T8HP), High Output T8 or T5 instead of Metal Halide, Pulse-Start Metal Halide instead of Standard Metal Halide, CLF and Ceramic Metal Halide instead of Incandescent.

Weighted LPD savings estimates include the LPD reduction possible in the fraction of stock that exceeds the target LPD level. Target LPD levels are lower than code. Estimate of stock with LPDs lower than the target are taken from case-weighted CBSA data for each vintage cohort. A three-step estimate of reduced LPD is made for each building subtype. Savings estimates apply only to the estimated fraction of floor area that does not meet the target LPDs. These are on the "Savings" tab.

Costs are incremental and based on 2003 cost information and estimate from various sources identified in the links below.

Proxy measures are used to determine estimated savings from a mix of measures. The proxy measures provide estimates of change in Watts and cost per change in LPD. LPD is measured in Watts per square foot and so represents normalized costs and savings information. Since ongoing lamp and ballast replacement costs figure prominently in cost-effectiveness, a mix of proxy measures is used to develop costs and savings by building sub type. The mix of measures and the applicability of each measure to each subtype has been calibrated to represent both existing stock of technology and fixture/lamp combinations by vintage cohort as well as the potential LPD change based on data taken from CBSA. Calibration achieved by matching the ability of the set of proxy measures to reduce the LPD to the target level. This calibration occurs in the tab "Costs".

Lighting savings yields (HVAC interactions) are applied by building sub type and space heat fuel source.

Standards”) by Eric Richman and Pam Cole of the Pacific Northwest National Laboratory on the website: http://ecmweb.com/market/electric_guiding_light/, accessed on May 5, 2009. 


\subsubsection{Results}

To summarize the results with respect to the commercial sector, the NWPPC identified about 1,600 average megawatts of technical conservation potential. Based upon expected wholesale electricity prices, nearly 90 percent of the technical potential was deemed to be cost-effective. ${ }^{7}$ The NWPPC estimated that, of this cost-effective potential, approximately 85 percent is "practically achievable," or about 1,100 average megawatts. This cost-effective and achievable resource is about 16 percent of the projected commercial sector energy use of 7,000 average megawatts.

NWPPC considered the conservation potential from both existing and new buildings over the 20-year time horizon. However, rather than categorizing the savings as either from new or existing buildings, the Fifth Plan report distinguishes between lost-opportunity resources and retrofit (or "dispatchable") resources. Lost-opportunity resources are those measures that must be undertaken when buildings are constructed or remodeled and when new or replacement equipment is purchased. Retrofit resources are considered in the report as dispatchable because the timing of building and equipment retrofits can be influenced by programmatic activities.

Tables 3.6 and 3.7 show the lost-opportunity and retrofit measures identified by the NWPCC as being cost-effective and "realistically achievable" by 2025. About 60 percent of the total of the roughly 1,100 average megawatts of potential is accounted for by lost-opportunity measures.

Table 3.8 is drawn from the two tables above but shows only those measures pertaining to existing buildings. The measures for commercial infrastructure (e.g., municipal water supply) were omitted. Several individual entries were adjusted in this process. As discussed in the NWPCC report, the measure for efficient power converters actually included savings from the residential and industrial sectors, as well as the commercial. Fifty percent of these savings (78 MWa) were assumed to accrue to commercial buildings. The lost-opportunity assessment included 101 average megawatts for lighting equipment. Again, half of these savings were assumed to be applicable to existing buildings. This revised list of measures was ordered in terms of levelized cost, as shown in the third column of Table 3.8.

The total potential for existing commercial buildings after making these adjustments is just under 650 average megawatts. Assuming that commercial buildings would account for approximately 90 percent of total commercial sector electricity sales in $2025^{8}$, this

\footnotetext{
${ }^{7}$ In the Fifth Plan report, it appears that no measures with levelized costs exceeding about 7 cents/kWh were considered as part of technical potential, helping to explain the high ratio of economic to technical potential.

${ }^{8}$ At a national level, identified components of non-building commercial electricity use (street lighting, water supply and treatment, and cell towers) in a recent PNNL study (Belzer 2007) accounted for about 8 percent of commercial sector electricity consumption. There are other miscellaneous non-building uses that would add to that total.
} 
Table 3.6: Commercial Sector Lost-Opportunity Measures (NWPPC Fifth Power Plan)

\begin{tabular}{lccc} 
Measure & $\begin{array}{c}\text { Average } \\
\text { Cost-Effective } \\
\text { Savings Potential } \\
\text { (MWa in 2025) }\end{array}$ & $\begin{array}{c}\text { Levelized } \\
\text { Cost } \\
\mathbf{( \$ / k W h )}\end{array}$ & $\begin{array}{c}\text { Benefit/Cost } \\
\text { Ratio }\end{array}$ \\
\hline Efficient AC/DC Power Converters & 156 & $\$ 0.015$ & 2.70 \\
Integrated Building Design & 152 & $\$ 0.023$ & 4.80 \\
Lighting Equipment & 101 & $\$ 0.003$ & 12.10 \\
Packaged Refrigeration Equipment & 68 & $\$ 0.019$ & 1.90 \\
Low-Pressure Distribution & 47 & $\$ 0.027$ & 1.60 \\
Skylight Day Lighting & 34 & $\$ 0.034$ & 1.60 \\
Premium Fume Hood & 16 & $\$ 0.037$ & 1.00 \\
Municipal Sewage Treatment & 11 & $\$ 0.014$ & 2.40 \\
Roof Insulation & 12 & $\$ 0.015$ & 2.10 \\
Premium HVAC Equipment & 9 & $\$ 0.043$ & 1.20 \\
Electrically Commutated Fan Motors & 9 & $\$ 0.024$ & 1.80 \\
Controls Commissioning & 9 & $\$ 0.037$ & 1.10 \\
Variable Speed Chillers & 4 & $\$ 0.031$ & 1.60 \\
High-Performance Glass & 6 & $\$ 0.030$ & 1.40 \\
Perimeter Day Lighting & 1 & $\$ 0.063$ & 0.90 \\
& & & \\
Total & 634 & $\$ 0.019$ & 4.30 \\
Source: Table D-5 (NWPPC 2005) & & &
\end{tabular}

Table 3.7: Commercial Sector Retrofit Measures (NWPPC Fifth Power Plan)

\begin{tabular}{lccc} 
Measure & $\begin{array}{c}\text { Cost-Effective } \\
\text { Savings Potential } \\
\text { (MWa in 2025) }\end{array}$ & $\begin{array}{c}\text { Average } \\
\text { Levelized } \\
\text { Cost } \\
\text { (\$/kWh) }\end{array}$ & $\begin{array}{c}\text { Benefit/Cost } \\
\text { Ratio }\end{array}$ \\
\hline Lighting Equipment & 114 & $\$ 0.018$ & 2.2 \\
Small HVAC Optimization and Repair & 75 & $\$ 0.032$ & 1.4 \\
Network Personal Computer Power Mgmt. & 61 & $\$ 0.028$ & 1.3 \\
LED Exit Signs & 36 & $\$ 0.023$ & 1.6 \\
Large HVAC Optimization and Repair & 38 & $\$ 0.037$ & 1.2 \\
Grocery Refrigeration Upgrade & 34 & $\$ 0.019$ & 1.9 \\
Office Plug Load Sensor & 13 & $\$ 0.031$ & 1.2 \\
High-Performance Glass & 9 & $\$ 0.029$ & 1.3 \\
Adjustable Speed Drives & 3 & $\$ 0.043$ & 1.1 \\
Municipal Water Supply & 25 & $\$ 0.033$ & 1.2 \\
Municipal Sewage Treatment & 37 & $\$ 0.014$ & 2.4 \\
LED Traffic Lights & 8 & $\$ 0.019$ & 1.8 \\
& & & \\
Total & 453 & $\$ 0.025$ & 1.8
\end{tabular}

Source: Table D-7 (NWPPC 2005) 
Table 3.8: Estimated Potential for Existing Commercial Buildings in the Pacific Northwest

\begin{tabular}{|c|c|c|c|c|}
\hline & $\begin{array}{c}\text { Cost- } \\
\text { Effective } \\
\text { Savings } \\
\text { Potential } \\
\text { (MWa in } \\
\text { 2025) }\end{array}$ & $\begin{array}{l}\text { Cumulative } \\
\text { Savings } \\
\text { (MWa in } \\
\text { 2025) }\end{array}$ & $\begin{array}{l}\text { Average } \\
\text { Levelized } \\
\text { Cost } \\
(\$ / \mathrm{kWh})\end{array}$ & $\begin{array}{c}\text { Benefit } \\
\text { ICost } \\
\text { Ratio }\end{array}$ \\
\hline Lighting Equipment & 50.5 & 50.5 & $\$ 0.003$ & 12.1 \\
\hline Efficient AC/DC Power Converters & 78 & 128.5 & $\$ 0.015$ & 2.7 \\
\hline Roof Insulation & 12 & 140.5 & $\$ 0.015$ & 2.1 \\
\hline Lighting Equipment & 114 & 254.5 & $\$ 0.018$ & 2.2 \\
\hline Packaged Refrigeration Equipment & 68 & 322.5 & $\$ 0.019$ & 1.9 \\
\hline Grocery Refrigeration Upgrade & 34 & 356.5 & $\$ 0.019$ & 1.9 \\
\hline LED Exit Signs & 36 & 392.5 & $\$ 0.023$ & 1.6 \\
\hline Electrically Commutated Fan Motors & 9 & 401.5 & $\$ 0.024$ & 1.8 \\
\hline Network Personal Computer Power Mgmt. & 61 & 462.5 & $\$ 0.028$ & 1.3 \\
\hline High-Performance Glass - retrofit & 9 & 471.5 & $\$ 0.029$ & 1.3 \\
\hline High-Performance Glass - lost opportunity & 6 & 477.5 & $\$ 0.030$ & 1.4 \\
\hline Variable Speed Chillers & 4 & 481.5 & $\$ 0.031$ & 1.6 \\
\hline Office Plug Load Sensor & 13 & 494.5 & $\$ 0.031$ & 1.2 \\
\hline Small HVAC Optimization and Repair & 75 & 569.5 & $\$ 0.032$ & 1.4 \\
\hline Premium Fume Hood & 16 & 585.5 & $\$ 0.037$ & 1.0 \\
\hline Controls Commissioning & 9 & 594.5 & $\$ 0.037$ & 1.1 \\
\hline Large HVAC Optimization and Repair & 38 & 632.5 & $\$ 0.037$ & 1.2 \\
\hline Premium HVAC Equipment & 9 & 641.5 & $\$ 0.043$ & 1.2 \\
\hline Adjustable Speed Drives & 3 & 644.5 & $\$ 0.043$ & 1.1 \\
\hline Perimeter Day Lighting & 1 & 645.5 & $\$ 0.063$ & 0.9 \\
\hline Total & 645.5 & & & \\
\hline
\end{tabular}

potential would represent a little over 10 percent of 2025 commercial building consumption $[645 /(7,000-700)=0.103]$.

The conservation supply curve based on the values shown in Table 3.8 is displayed in Figure 3.5. 


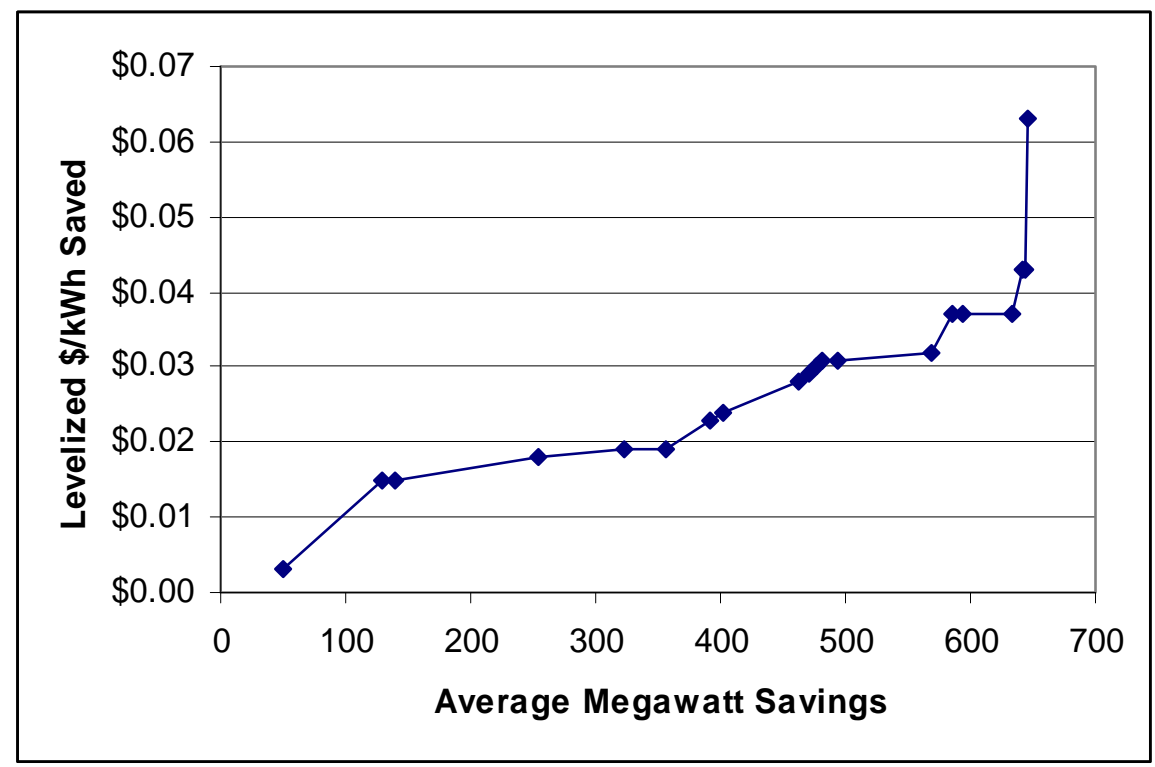

Figure 3.5: Estimated Conservation Supply Curve for Existing Northwest Commercial Buildings.

As shown in Figure 3.6, the relative contribution of lighting upgrades is somewhat smaller according the NWPPC study, in comparison to the previous two studies (California and Connecticut).

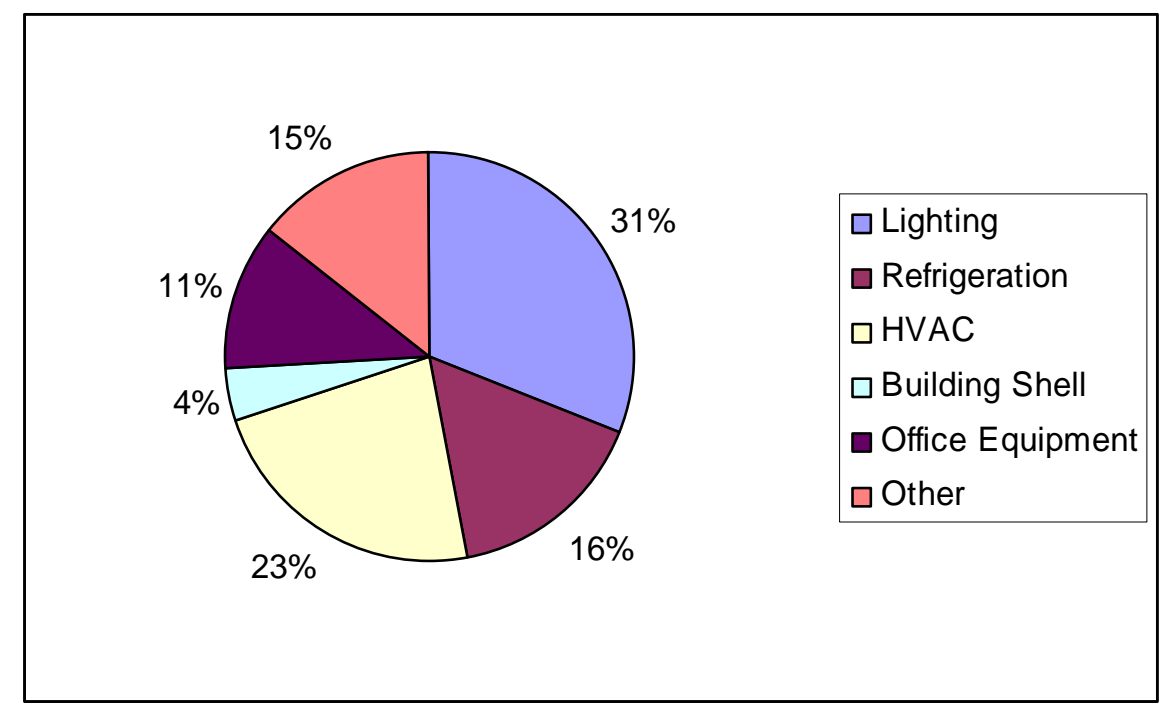

Figure 3.6: Distribution of Cost Effective Achievable Savings - 2005 NWPPC Study 


\subsection{Vermont Electric Energy Efficiency Study (2006)}

In mid-2006 GDS Associates completed a comprehensive study of electricity energyefficiency potential through 2015 for the state of Vermont (GDS Associates 2006). The study was prepared for the Vermont Department of Public Service. GDS was assisted by experts from several other organizations including Efficiency Vermont and the American Council for an Energy Efficient Economy.

\subsubsection{Scope}

The GDS report covered the three major electricity using sectors: residential, commercial, and industrial. For the buildings sectors, efficiency potential from existing and new buildings was assessed. The report focused upon the achievable savings that could be captured by 2015 .

\subsubsection{Key Data Sources}

GDS reported that it made use of over 200 existing studies conducted in Vermont and throughout the U.S. on the potential energy savings, cost, and penetration of energyefficiency measures. A key source for Vermont was the Efficiency Vermont Technical Reference User Manual, periodically updated by Efficiency Vermont. Other sources included the California Statewide Commercial Energy Efficiency Study (summarized in Section 3.1 of this report), the prior study in 2004 by GDS Associates, the New York State Energy Research and Development Administration (NYSERDA), and information from the Maine Cost-Effectiveness Model.

\subsubsection{Results}

The aggregate results for commercial buildings suggest a large technical potential for savings, just over 40\% of projected 2015 electricity use in the sector. However, a major portion of this potential was deemed to not be achievable by 2015. Table 3.9 summarizes the aggregate measures of efficiency potential developed in the study. As discussed in Section 2.0, achievable potential recognizes that some measures will only be installed when equipment is normally replaced, and some equipment will not be replaced by 2015 . Second, as in their Connecticut study, GDS applied a blanket assumption that only 80\% of the technical potential of each measure can be realistically achieved. Most of the measures that GDS analyzed from the outset were cost effective, as the cost- effective achievable savings (shown at the bottom of the table) is nearly $90 \%$ of the achievable savings. 
Table 3.9: Aggregate Commercial Electricity Potential in Vermont

\begin{tabular}{lcc} 
& $\begin{array}{c}\text { Estimated GWh } \\
\text { Savings }\end{array}$ & $\begin{array}{c}\text { Percent } \\
\text { Savings of } \\
2015 \\
\text { Commercial } \\
\text { Sector kWh } \\
\text { Sales }\end{array}$ \\
\hline Technical Potential & $\mathbf{8 5 4 . 2}$ & $\mathbf{4 0 . 4 \%}$ \\
Existing Buildings & 844.3 & $40.5 \%$ \\
$\quad$ New Construction & 9.9 & $31.4 \%$ \\
Achievable & $\mathbf{5 1 6 . 3}$ & $\mathbf{2 4 . 4 \%}$ \\
Potential (2015) & & \\
$\quad$ Existing Buildings & 509.1 & $24.4 \%$ \\
$\quad$ New Construction & 7.2 & $22.9 \%$ \\
Achievable Cost & $\mathbf{4 5 0 . 4}$ & $\mathbf{2 1 . 3 \%}$ \\
Effective Potential & & \\
(2015) & & $21.3 \%$ \\
$\quad$ Existing Buildings & 444.3 & $19.4 \%$ \\
New Construction & 6.1 & \\
Projected 2015 & & \\
Commercial & $\mathbf{2 , 1 1 5}$ & \\
Electricity Use & &
\end{tabular}

As in all other studies, lighting represents the largest fraction of potential savings. Figure 3.7 shows the distribution of cost-effective achievable savings. Perhaps most notable in this figure is the very high proportion of the total savings attributable to efficiency measures related to refrigeration.

The high percentage of refrigeration savings stems in large part from the large fraction of commercial electricity use that was estimated for this end use. The study cites estimates for New York that indicated a high proportion of commercial electricity use for refrigeration. Figure 3.8 shows the estimates breakdown on electricity by end use used in the Vermont study. 


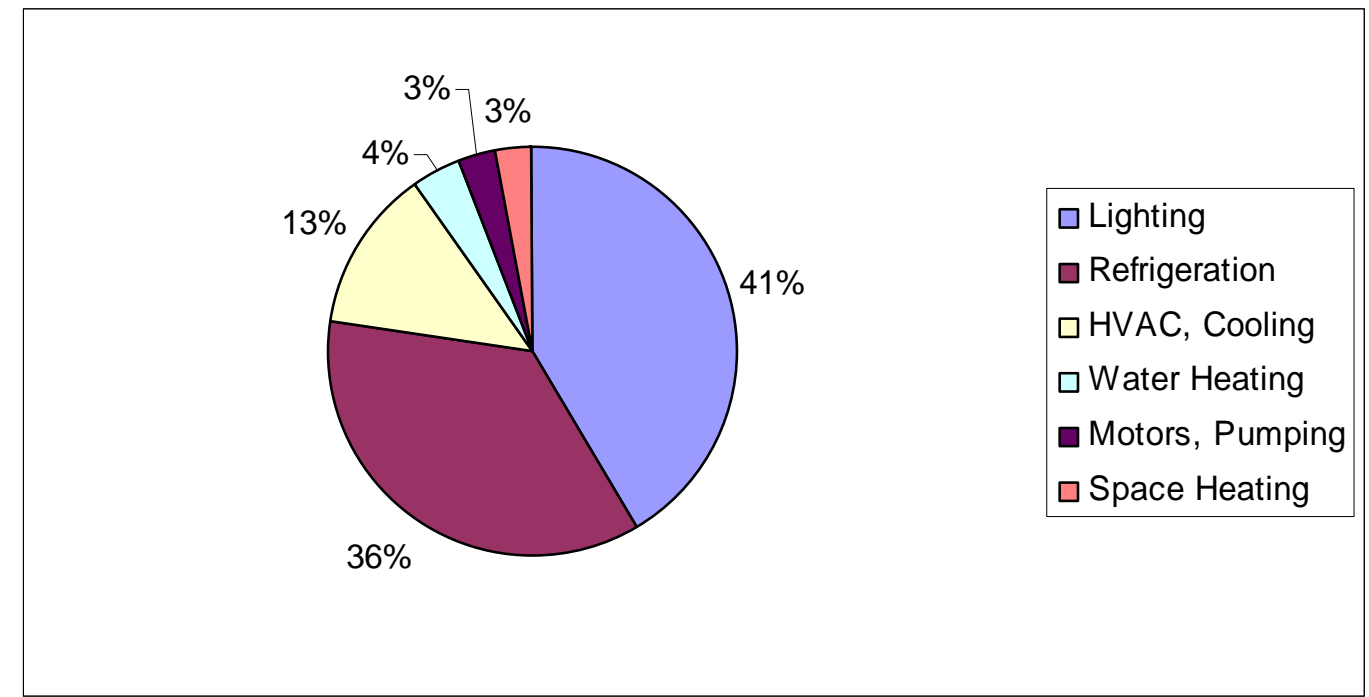

Figure 3.7: Distribution of Cost-Effective Achievable Savings by End Use for Vermont

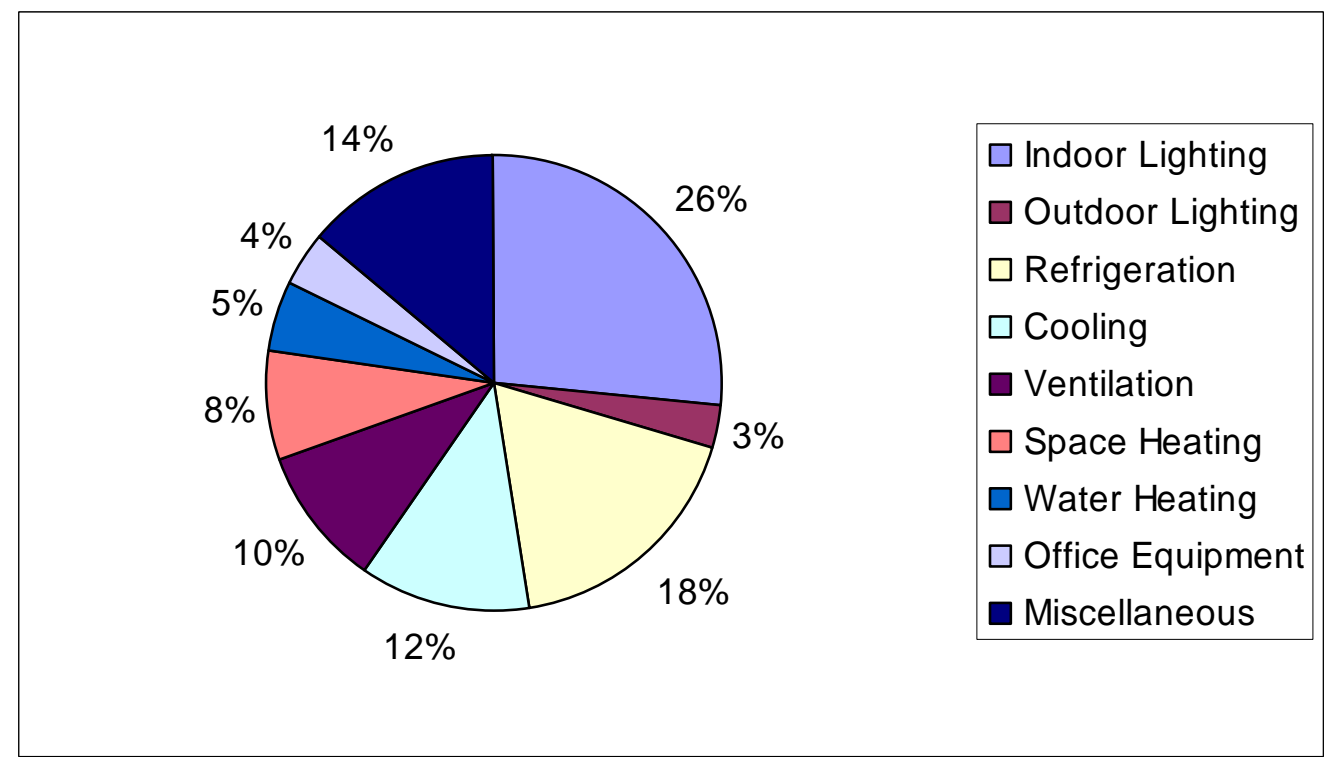

Figure 3.8: Distribution of Baseline Commercial Electricity Consumption by End Use in Vermont 


\subsection{Colorado DSM Market Potential Assessment (2006)}

In 2005, the Colorado Public Utilities Commission directed Xcel Energy to conduct a demand side management (DSM) assessment of energy efficiency. The assessment was performed by KEMA (2006), using much of the same methodology as in their prior studies in California (e.g., Xenergy 2002a, 2002b).

\subsubsection{Scope}

This study examined electricity efficiency potential in the area in Colorado served by the Xcel Energy. Xcel Energy is the primary utility in Colorado, serving the metropolitan Denver area and several other municipalities in the state. In the study, three types of energy-efficiency potential were estimated:

- Technical potential, defined as the complete penetration of all measures analyzed in applications where they were deemed technically feasible

- Economic potential, defined as the technical potential of those energy-efficiency measures that are cost effective when compared to supply-side alternative

- Achievable potential, the amount of savings that would occur in response to specific program funding and measure incentive levels.

The Colorado study estimated these potentials over the ten-year period from 2006 through 2015, although the main focus of the report was the eight-year period ending in 2013. All major end-use sectors were considered in the study: residential, commercial, and industrial. In several areas, the commercial potential is broken out into existing and new buildings.

\subsubsection{Key Data Sources}

As cited in the report, the study data "come from a number of sources, including primary data collected for this project, secondary sources that include internal Xcel Energy studies and data, as well as a variety of information from third parties.” The primary data collection effort was extensive for a single utility service territory. Data were collected from 300 residential on-site surveys, 152 commercial on-site surveys, and 193 vendor telephone surveys.

\section{Baseline Technology Market Shares}

The baseline technology shares were generally based upon the on-site surveys just mentioned. The telephone surveys with vendors were used to supplement this information. The telephone surveys included discussions with:

- Air conditioning equipment distributors, contractors, and designers

- Lighting distributors, contractors, and designers

- Residential builders 
- Industrial motor and compressed air vendors

Data from the Commercial Building Energy Consumption Survey (CBECS) for the Mountain census division were also employed to estimate end-use saturations (shares of total floor space employing a specific end use) and equipment shares. ${ }^{9}$

The on-site and telephone surveys focused primarily upon lighting and cooling. The information on lighting is particularly useful because it presents a recent assessment of technology shares by floor space.

The Colorado study is noteworthy as it provides a detailed (and recent) picture of the types of technologies currently installed in existing commercial buildings. As an example, Figure 3.9 shows the distribution of indoor lighting technologies from the Colorado study. As seen in the figure, the study estimated that the two categories of fixtures including from one to four fluorescent lamps, accounts for 60 percent of total floor space. Point sources (incandescent or CFL) accounts for about 20 percent of total floor space.

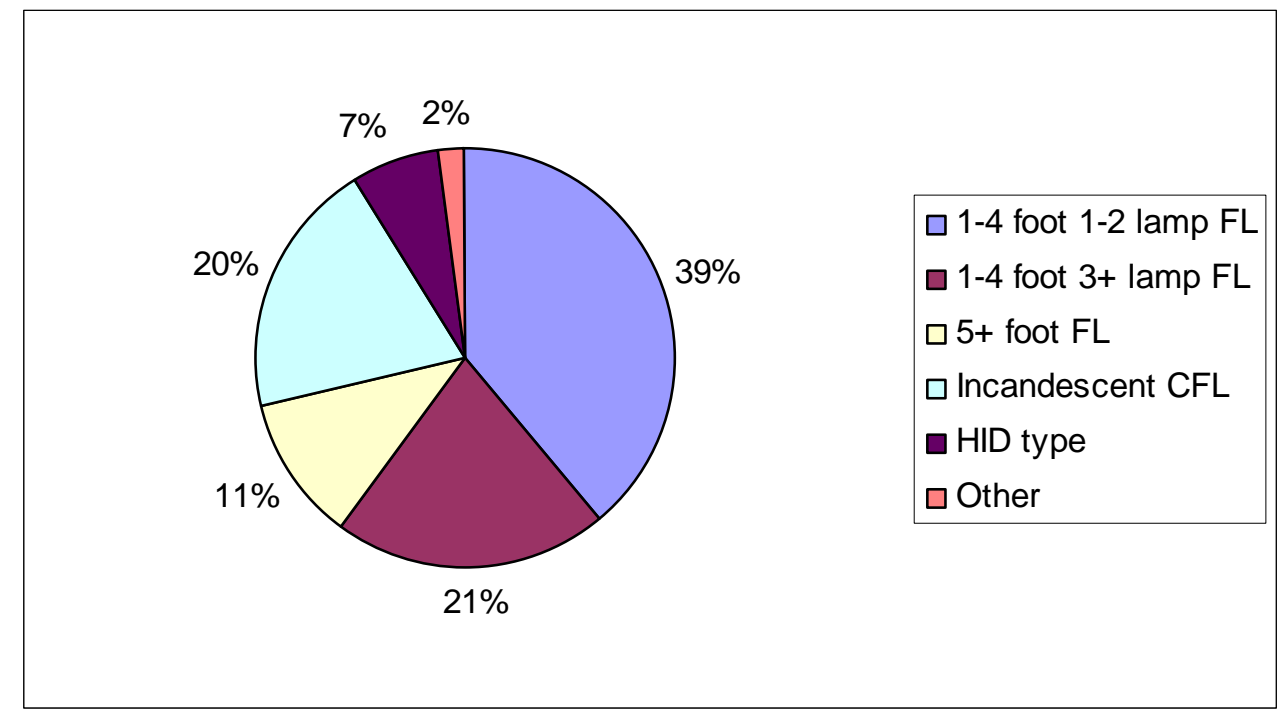

Figure 3.9: Distribution of Commercial Indoor Lighting Technologies by Floor Space (KEMA 2006).

Figure 3.10 is also taken from the Colorado report and shows a breakdown of lighting by fluorescent type. The study found that about half of the floor space already had converted to T8 or T5 systems, including 6 percent of floor space with "premium T8" systems. KEMA estimates that the premium T8 systems are about $15 \%$ more efficient compared to the first- and second-generation T8 lamps and ballasts.

\footnotetext{
${ }^{9}$ Based upon PNNL's experience in using CBECS at the census division level (with relatively few observations), the statistical validity of these saturations must be questioned. For some end uses, the differences between northern and southern portions of the Mountain census division would likely be large.
} 


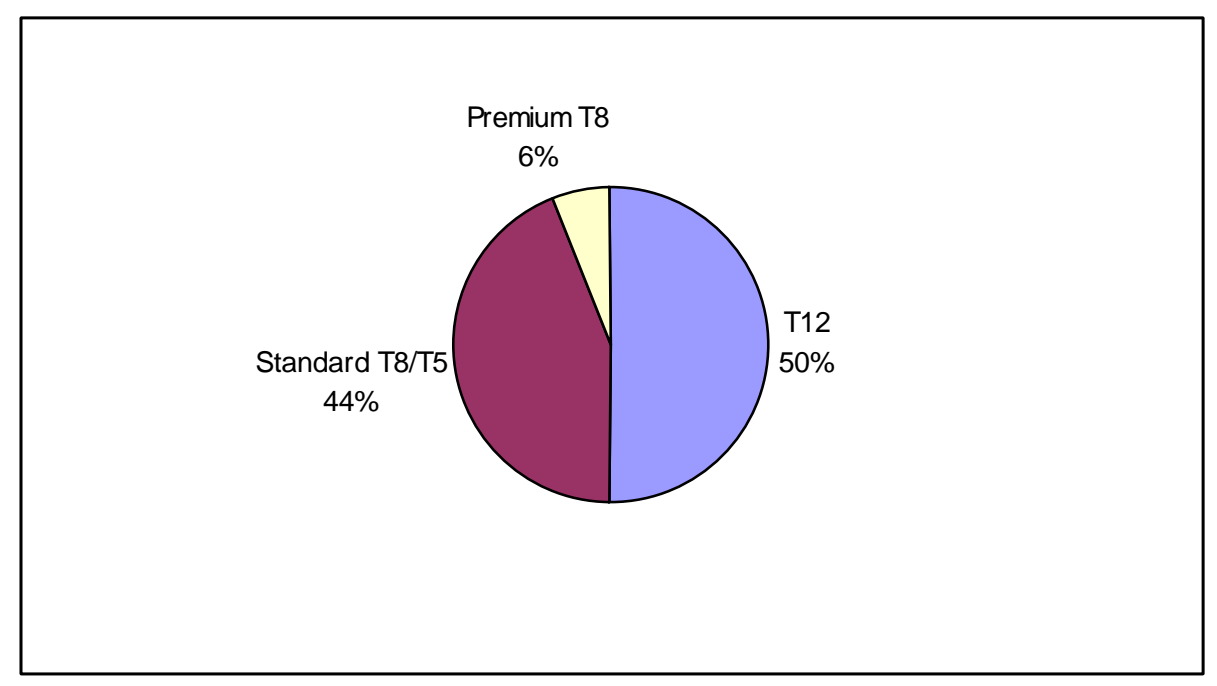

Figure 3.10: Distribution of Linear Fluorescent Fixtures by Efficiency Type

Consistent with the earlier findings from the 2002 California study, the on-site surveys conducted by KEMA indicated that the penetration of T8 technologies was higher in larger buildings than small buildings. Table 3.10 summarizes the findings from their study and shows that less than one-quarter of the floor space in small commercial buildings ( $<10,000$ square feet) has installed T8 fixtures.

\section{Table 3.10: T8 Saturations by Building Size}

\begin{tabular}{|l|l|}
\hline Building Size & Penetration \\
\hline Small (<10,000 sf) & $23 \%$ \\
\hline $\begin{array}{l}\text { Medium (10,000 to 100,000 } \\
\text { sf) }\end{array}$ & $44 \%$ \\
\hline Large ( $>100,000$ sf) & $78 \%$ \\
\hline
\end{tabular}

Source: Figure 3-15 (KEMA 2006)

The use of reflectors is cited by KEMA as a cost-effective opportunity to reduce lighting electricity use in commercial buildings. Based upon the surveys, KEMA found that about $15 \%$ of fluorescent lighting already has reflectors. Reflectors can be cost effective because they provide a means of reducing the number of lamps in the fixture. As KEMA notes in their report, "based upon surveyor judgment, after review of current installations and current lighting levels in commercial buildings, it appears that installation of reflectors may be feasible in over 50 percent of the remaining fluorescent lighting applications.”

\subsubsection{Results}

KEMA estimated technical electricity efficiency potential in the commercial sector to be about 22 percent of projected 2013 usage. Economic potential was estimated to be $17 \%$. The study did not break out potential between existing and new buildings, but given the 
relatively short forecast horizon, it can be assumed that over $90 \%$ of these savings can be attributed to existing buildings.

The overwhelming proportion (> two-thirds) of economic potential was determined to stem from lighting efficiency measures. Figure 3.11 shows the distribution of potential (economic) savings by end use.

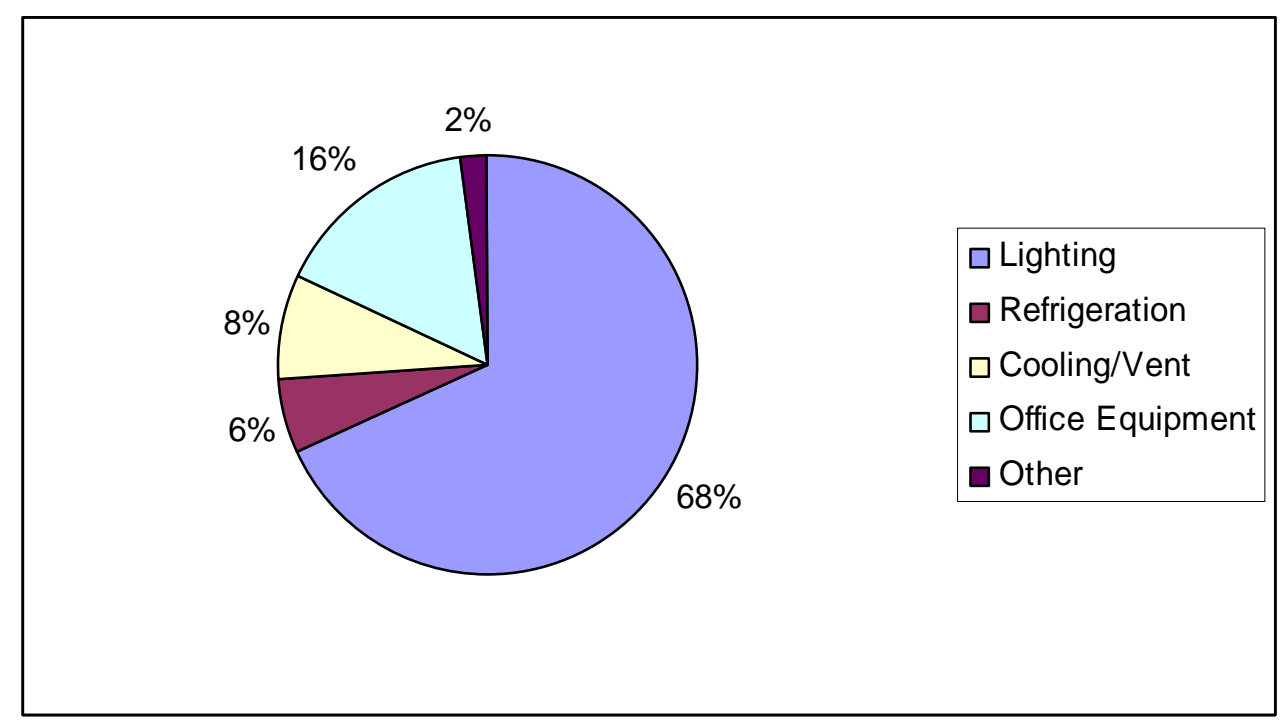

\section{Figure 3.11: Distribution of Economic Potential by End Use for Xcel Energy (Colorado)}

Because the KEMA study for Xcel yielded such a high percentage of total savings attributable to lighting, it may be useful to take a closer look at lighting savings. The Colorado study is notable for the use of on-site surveys that provide some estimates of the types of lighting technologies currently in place.

Table 3.11 provides a complete listing of the lighting measures considered by KEMA for the Xcel study. The top portion of the table shows the measures associated with linear fluorescent technologies, all of which move to premium (or "Super”) T8 lamps, with improved electronic ballasts. Taken together, the linear fluorescent measures account for about 45 percent of the total lighting potential. CFLs represent the next largest savings category, accounting for roughly one-third of the total.

Occupancy sensors and controls are estimated to have the potential of saving about 170 MWh of electricity use by 2013. These measures were analyzed separately by building type and have different levelized cost savings accordingly. These individual elements are shown in the table. ${ }^{10}$ The KEMA study also examined outdoor lighting and several other measures, as shown in the bottom two panels of the table.

\footnotetext{
${ }^{10}$ The multiple entries for lighting control tune-up reflect different space and building types where costeffectiveness differs, but were not specifically identified in the KEMA report.
} 


\section{Table 3.11: Lighting Savings for Individual Measures for (KEMA) Colorado Study}

\section{Linear fluorescent}

RET T-12 to Premium T-8, Reflector

ROB 2L4' Premium T8

ROB 4L4' Premium T8

RET 2 - 1L4' Premium T8

RET 4L4' Premium T8, 1 EB

RET 2L4' Premium T8, 1 EB

RET 2 - 2L4' Premium T8, 1 EB

RET 1L4' Premium T8, 1EB, Reflec., OEM

Total

CFL

Screw-in

CFL hard-wired, Modular $18 \mathrm{~W}$

Total

\section{Occupancy sensor and controls}

Lighting control tune-up

Lighting control tune-up

Lighting control tune-up

Lighting control tune-up

Occ. Sensor, 8L4' Fluorescent Fixtures

Occ. Sensor, 8L4' Fluorescent Fixtures

Occ. Sensor, 4L8' Fluorescent Fixtures

Occ. Sensor, 4L4' Fluorescent Fixtures

Occ. Sensor, 4L4' Fluorescent Fixtures

Total

\section{Outdoor lighting}

Outdoor lighting controls (photocell/timeclock)

High pressure sodium 250W lamp

Total

\section{Other}

LED Exit Sign

High Bay T5

Total

\section{All Lighting Measures}

\begin{tabular}{rr} 
MWh Savings & $\$ / \mathrm{kWh}$ \\
\hline 144.7 & $\$ 0.008$ \\
90.8 & $\$ 0.015$ \\
78.3 & $\$ 0.018$ \\
19.0 & $\$ 0.018$ \\
259.8 & $\$ 0.021$ \\
229.8 & $\$ 0.030$ \\
28.9 & $\$ 0.041$ \\
29.6 & $\$ 0.045$ \\
$\mathbf{8 8 0 . 9}$ &
\end{tabular}

487.3

162.4

649.7

$3.5 \$ 0.014$

$2.2 \$ 0.016$

$3.8 \$ 0.016$

$2.0 \$ 0.020$

$40.3 \quad \$ 0.044$

$31.9 \$ 0.045$

$4.4 \$ 0.052$

$38.9 \$ 0.053$

$42.2 \$ 0.070$

169.2

$16.5 \$ 0.015$

$156.8 \$ 0.063$

173.3

$16.7 \$ 0.050$

$106.3 \$ 0.081$

1996.1

Notes: $\mathrm{RET}=$ retrofit, $\mathrm{ROB}=$ replace-on-burnout 


\subsection{Commonwealth Edison 2008-2010 Energy Efficiency and Demand Response Plan (2007)}

Commonwealth Edison (ComEd) submitted a comprehensive energy-efficiency and demand response plan to the Illinois Commerce Commission in November $2007 .{ }^{11}$ Much of detailed information in the plan was developed by ICF International. The plan is in response to landmark legislation passed by the Illinois legislature in 2007.

From the Executive Summary of the plan, the legislation (under a new Section 12-103 of the Public Utilities Act) will require Illinois utilities to invest significantly more dollars in expanded energy programs that, taken together, will lead Illinois to having the second highest (behind California) amount of energy-efficiency investment in the U.S.

\subsubsection{Scope}

The plan submitted by Commonwealth Edison covers all major end users - residential, commercial, and industrial. The detailed measures in the report appear to only apply to existing buildings and facilities.

\subsubsection{Key Data Sources}

The ComEd report exploited a wide variety of data sources to develop the empirical basis for it energy efficiency study.

\section{Measure Savings and Costs}

The most prevalent data source in the report is the California Database for Energy Efficient Resources (DEER), maintained by the California Public Utilities Commission (CPUC) and the California Energy Commission. ICF supplemented information from DEER with information it developed in work for other utilities and other studies of energy-efficiency potential by ComEd, the Ameren Illinois Utilities, and the Illinois Department of Commerce and Economic Opportunity (DCEO). With regard to cost data, in some cases data were taken from non-DEER sources, including on-line price quotes for appliances, EPA Energy Star calculators, or calls to retailers or installers. ICF also considered weather-sensitive measures such as upgrading windows and insulation. The savings for these measures were based on DOE-2 simulations run for prototypical buildings in the ComEd service area.

\section{Technology Shares}

The ComEd report terms the existing technology share as "Relevance," defined generally as a measure of applicability based on saturation. The example cited in the report is the percentage of central air conditioning. Upon perusal, the tables in Appendix B of the report do not identify the sources for these values. As stated in the guide to the specific tables, "ComEd-specific baseline information was very limited." For the most part, ICF assumptions, or state, regional, or national data were used to develop proxy values.

${ }^{11}$ Commonwealth Edison, owned by Exelon Corporation, serves Chicago and northern Illinois. 


\section{Existing Energy-Efficient Measure Saturations}

The empirical basis, in terms of specific sources, for the current penetration of the energy-efficient measures considered in the report is relatively sparse. Table 3.12 summarized the "Not Yet Adopted" percentages used by ICF in some the key commercial building-related efficiency measures.

Table 3.12: Values for Saturation for Selected Commercial Efficiency Measures ComEd Efficiency Report

\begin{tabular}{|l|c|}
\hline \multicolumn{1}{|c|}{ Measure or Measure Type } & $\begin{array}{c}\text { Not Yet Adopted } \\
\text { (\%) }\end{array}$ \\
\hline Integral or Modular CFL & \\
\hline Large, Small Office & $51 \%$ \\
\hline Large Retail & $80 \%$ \\
\hline Education, Assembly & $75 \%$ \\
\hline Food Service & $96 \%$ \\
\hline Health Care & $25 \%$ \\
\hline Food Sales & $83 \%$ \\
\hline Lodging & $37 \%$ \\
\hline T8/Electronic Ballast (All efficiencies + Super T8) & $95 \%$ \\
\hline Occupancy Sensor (plug loads or lighting) & $75 \%$ \\
\hline LED Exits Signs & $75 \%$ \\
\hline Variable Speed Drives for Chilled Water Loops & $75 \%$ \\
\hline Energy Efficient Chiller & $75 \%$ \\
\hline Light colored roof & $75 \%$ \\
\hline Economizer retrofit & $75 \%$ \\
\hline VAV box retrofit on constant volume system & $75 \%$ \\
\hline
\end{tabular}

Source: Tabular information in Appendix B (ComEd 2007)

\subsubsection{Results}

The analysis conducted by ICF International appears to be very focused on those areas with highest potential for short-term and cost-effective electricity savings. The plan itself is mostly concerned with laying out the major elements of the new programs ComEd is proposing to implement in the next three years and the goals for each program. Accordingly, the plan does not assemble the total energy-efficiency potential, either by sector or in total.

Notwithstanding ComEd's comments about the aggressive nature of the anticipated efficiency programs, the statewide goals under the legislation appear to be fairly modest. It should be noted that the goals are set forth under the constraint that electricity prices, caused by the demand-side programs, cannot exceed specified limits. Table 3.13 summarizes the energy and demand goals of the legislation, along with the limits on future electricity prices under the "spending screen." 
Table 3.13: Legislative Goals for Energy Efficiency and Demand Response for Illinois

\begin{tabular}{|l|l|l|l|l|l|l|l|l|}
\hline $\begin{array}{l}\text { Year } \\
\text { Commencing } \\
\text { June 1 }\end{array}$ & $\mathbf{2 0 0 8}$ & $\mathbf{2 0 0 9}$ & $\mathbf{2 0 1 0}$ & $\mathbf{2 0 1 1}$ & $\mathbf{2 0 1 2}$ & $\mathbf{2 0 1 3}$ & $\mathbf{2 0 1 4}$ & $\mathbf{2 0 1 5}$ \\
\hline $\begin{array}{l}\text { Energy } \\
\text { Efficiency (\% of } \\
\text { energy } \\
\text { delivered) }\end{array}$ & $0.2 \%$ & $0.4 \%$ & $0.6 \%$ & $0.8 \%$ & $1.0 \%$ & $1.4 \%$ & $1.8 \%$ & $2.0 \%$ \\
\hline $\begin{array}{l}\text { Demand } \\
\text { Response (\% of } \\
\text { prior year peak } \\
\text { demand) }\end{array}$ & $0.1 \%$ & $0.1 \%$ & $0.1 \%$ & $0.1 \%$ & $0.1 \%$ & $0.1 \%$ & $0.1 \%$ & $0.1 \%$ \\
\hline $\begin{array}{l}\text { Spending Screen } \\
\text { (Max. increase } \\
\text { in rate per kWh }\end{array}$ & $0.5 \%$ & $1.0 \%$ & $1.5 \%$ & $2.0 \%$ & $2.015 \%$ & $2.015 \%$ & $2.015 \%$ & $2.015 \%$ \\
\hline
\end{tabular}

Source: Table 3 (ComEd 2007).

While the plan does not provide the intermediate efficiency potential from various measures, it does identify those measures passing the screening defined by economic efficiency. Of 942 commercial sector measures analyzed by ICF, 692 (73\%) were judged to be cost effective. The key types of measures passing and (failing) the cost-effective tests are shown in Table 3.14. 
Table 3.14: Types of Measures Passing and Failing Cost-Effectiveness Tests

\begin{tabular}{|c|c|c|}
\hline Measure & Cost Effective (Yes, No) & $\begin{array}{c}\text { Range of Values for TRC } \\
\text { Test }\end{array}$ \\
\hline $\begin{array}{l}\text { T12 to T8 linear } \\
\text { fluorescent lamps }\end{array}$ & Yes & $\begin{array}{l}\text { Values range from less than } \\
1(0.36) \text { to as high as } 4 \text {, for } \\
\text { office buildings }\end{array}$ \\
\hline Compact florescent lamps & Yes & Most values exceed 2 \\
\hline LED exit signs & Yes & $\begin{array}{l}\text { Values for all building types } \\
\text { exceed } 2\end{array}$ \\
\hline $\begin{array}{l}\text { Computer power } \\
\text { management }\end{array}$ & Yes & $\begin{array}{l}\text { Specified only for large } \\
\text { office, TRC greater than } 4\end{array}$ \\
\hline $\begin{array}{l}\text { Variable speed drives - } \\
\text { chilled and hot water loops }\end{array}$ & Yes & $\begin{array}{l}\text { Applicable to office, } \\
\text { education, and lodging. } \\
\text { TRC values over } 2 \text { for } \\
\text { chilled water, over } 7 \text { for hot } \\
\text { water loops }\end{array}$ \\
\hline $\begin{array}{l}\text { New packaged air } \\
\text { conditioning units }\end{array}$ & Yes & $\begin{array}{l}\text { TRC values generally range } \\
\text { from } 1.5 \text { to a little over } 2\end{array}$ \\
\hline Efficient chillers & Yes & $\begin{array}{l}\text { TRC values over } 3 \text { for large } \\
\text { office, hotel, and hospital }\end{array}$ \\
\hline $\begin{array}{l}\text { Variable air volume } \\
\text { retrofits }\end{array}$ & Yes & $\begin{array}{l}\text { TRC values range from } 2 \text { to } \\
\text { over } 30 \text {, depending upon } \\
\text { building type }\end{array}$ \\
\hline $\begin{array}{l}\text { Commercial refrigeration } \\
\text { controls and equipment } \\
\text { upgrades }\end{array}$ & $\begin{array}{l}\text { Yes (for majority of } \\
\text { measures) }\end{array}$ & $\begin{array}{l}\text { Some measures } \\
\text { (compressor upgrades, night } \\
\text { covers) not cost-effective }\end{array}$ \\
\hline $\begin{array}{l}\text { Occupancy sensors - } \\
\text { lighting }\end{array}$ & Yes & $\begin{array}{l}\text { Values for most building } \\
\text { types near } 1.5\end{array}$ \\
\hline $\begin{array}{l}\text { Occupancy sensors - plug } \\
\text { loads }\end{array}$ & No & $\begin{array}{l}\text { Value for most building } \\
\text { type near } 0.5\end{array}$ \\
\hline $\begin{array}{l}\text { Upgrade roof insulation to } \\
\text { current standard }\end{array}$ & $\begin{array}{l}\text { Yes (for } 3 \text { of } 12 \text { building } \\
\text { types) }\end{array}$ & $\begin{array}{l}\text { Marginally cost-effective } \\
\text { for three building types }\end{array}$ \\
\hline Light colored roof & No & \\
\hline $\begin{array}{l}\text { Add economizer to existing } \\
\text { system }\end{array}$ & No & $\begin{array}{l}\text { Not cost effective for any } \\
\text { building type }\end{array}$ \\
\hline
\end{tabular}




\section{Comparison of Key Results}

In comparing the results across studies, we looked at total potential as well as the potential for the typically-largest end use, lighting.

\subsection{Total Potential}

Table 4.1 compares total technical and economic potential from the first five studies examined in the previous section ${ }^{12}$.

Table 4.1: Comparison of Total Technical and Economic Efficiency Potentials

\begin{tabular}{|c|c|c|c|c|c|c|}
\hline & \multirow{2}{*}{$\begin{array}{c}\text { Base } \\
\text { Consumption } \\
\text { (GWh) }\end{array}$} & \multicolumn{2}{|c|}{ Technical Potential } & \multicolumn{2}{|c|}{$\begin{array}{c}\text { Economic } \\
\text { Potential }\end{array}$} & \multirow[t]{2}{*}{$\begin{array}{l}\text { Year of Base } \\
\text { Consumption }\end{array}$} \\
\hline & & GWh & Percent & GWh & Percent & \\
\hline California & 80,000 & 14,731 & $18.4 \%$ & 10,627 & $13.3 \%$ & 2000 \\
\hline Connecticut & 14,591 & 3,703 & $25.4 \%$ & 3,063 & $21.0 \%$ & 2012 \\
\hline NWPPC & 7,000 & 843 & $12.0 \%$ & 759 & $10.8 \%$ & 2000 \\
\hline Vermont & 2,115 & 854 & $40.4 \%$ & 726 & $34.3 \%$ & 2015 \\
\hline Colorado & 16,261 & 3,577 & $22.0 \%$ & 2,764 & $17.0 \%$ & 2013 \\
\hline
\end{tabular}

Notes:

1) California: Values shown apply to the three major private utilities in the state

2) Connecticut: Economic potential based upon estimated provided Appendix table (GDS Associates and Quantum Consulting 2004), and is not shown in main report,

3) NWPPC: Consumption and potential reported in terms of average megawatts. Reported "practically and economic achievable" savings is divided by 0.85 to account for NWPPC's assumption that only $85 \%$ of economic potential is practical.

4) Vermont: Economic potential is assumed to be $90 \%$ of technical potential

5) Colorado: Base consumption not shown in report (KEMA 2006): estimated from aggregate potentials and percentage savings shown in Figure 3-1 in report

Table 4.1 clearly shows a wide disparity in the estimates of technical and economic energy efficiency across the study areas. Besides differences in the building stock and climate, several other factors are at play here. First, the studies vary in the number of efficiency measures considered. For instance, the Colorado study did not consider an equivalent number of measures for refrigeration, as compared to most of the earlier studies. Second, the potential for California and the Pacific Northwest may indeed reflect the presumption that the long history of efficiency programs in these areas may have reduced the amount of additional potential in existing buildings.

\footnotetext{
${ }^{12}$ As explained in Section 3.6, the Commonwealth Edison report did not develop long-term energy savings potential estimates.
} 
Across the five studies, the range of economic potential is between 10 and 35\%.

However, the highest percentage potential for the Vermont may be in large part because of the special emphasis on refrigeration savings (that, in turn, reflects the very high estimate of electricity use for this end use). If the Vermont study is excluded, the range of savings narrows considerably, roughly spanning an interval of 10 to $20 \%$.

\subsection{Lighting}

One difficulty in comparing total energy-efficiency potentials across various studies is that the scope of the measures analyzed can vary. The treatment of lighting appears to have been more consistent, with key measures including replacement of existing linear fluorescent technologies with premium T8 lamps, substitution of the incandescent lamps with CFLs, and greater use of lighting controls.

Table 4.2 displays the technical and economic potential associated only with lighting measures. While California and the Pacific Northwest again show the smallest potential, the overall dispersion of the potential is smaller than for total potential. Across all five studies, the range of economic potential is between 3 and $12 \%$ of total electricity consumption (base level consumption for year in last column of the table).

Table 4.2: Energy Savings Potential from Lighting (All Measures)

\begin{tabular}{|l|c|c|c|c|c|c|}
\hline & $\begin{array}{c}\text { Base } \\
\text { Consumption }\end{array}$ & \multicolumn{2}{|c|}{ Technical Potential } & \multicolumn{2}{l|}{ Economic Potential } & $\begin{array}{l}\text { Year of Base } \\
\text { Consumption }\end{array}$ \\
\hline Study Area & $($ GWh $)$ & GWh & Percent & GWh & Percent & \\
\hline California & 80,000 & 7,368 & $6.7 \%$ & 5,377 & $6.7 \%$ & 2000 \\
\hline Connecticut & 14,593 & 1,550 & $10.6 \%$ & 1,070 & $7.3 \%$ & 2012 \\
\hline NWPPC & 7,000 & 235 & $3.4 \%$ & 235 & $3.4 \%$ & 2025 \\
\hline Vermont & 2,115 & 250 & $11.8 \%$ & 225 & $10.7 \%$ & 2015 \\
\hline Colorado & 16,261 & 1,905 & $11.7 \%$ & 1,905 & $11.7 \%$ & 2013 \\
\hline
\end{tabular}




\section{Summary and Conclusions}

The studies reviewed in this report all use detailed databases of energy-efficiency measures to develop estimates of total energy (electricity) efficiency potential. Based upon the results shown in Table 4.1, a reasonable range of economic savings potential in existing commercial buildings is between 10 and 20 percent. If lighting measures alone are considered, the range of economic savings falls in the range of 3 to 12 percent. In all studies reviewed, improved lighting was the end use with the largest technical and economic potential.

Both of the above ranges apply to total economic potential. As discussed in Section 3, the state and utility level reports generally assume that between of 70 to $85 \%$ of this potential is a maximum that can be achieved. Thus, on the level of specific programs, the potential savings are likely to be even lower. On the other hand, if we assume a target year further into the future as compared to most of these studies (e.g., 2030), it is quite likely that much of this potential may be achievable. The energy efficiency activities by utilities and states will likely accelerate the process by which what is now considered “energy efficient” (e.g., premium T8 lamps) to be standard practice a decade from now.

Several issues raised by these studies are relevant to the U.S. Department of Energy's efforts to reduce energy consumption in the nation's stock of commercial buildings.

1) Lighting. The studies clearly reveal that lighting is the end use that continues to have the largest and most cost-effective energy saving potential in existing commercial buildings. However, the majority of studies reviewed here were intended to guide utilities and state regulatory agencies with regard to expanding programs to capture a significant fraction of this potential. With regard to lighting technologies, these programs generally have the goal of installing highefficiency equipment (“premium” T8 lamps and compact CFLs). The programs generally assumed that much of the potential could only be captured on a "replace-on-burnout" mode, thus the full potential of these changes would take between 10 and 15 years to accomplish. If successful, much of the building stock will have these technologies in place in the 2015-2025 time frame. Having just upgraded these systems, it is natural to expect that building owners would be reluctant to prematurely replace these systems with solid-state lighting technology, unless the efficacy of solid-state system were dramatically greater than today's high-efficiency fluorescent technologies.

2) Refrigeration. Taken as a group, the studies examined here suggest that improvements in refrigeration systems and components are the second largest source of savings potential. As shown in Tables 3.2, 3.4, and 3.8, the measures related to refrigeration included night-time covers for display cases, as well as improved compressors and motors. With regard to more efficient equipment, one can expect that the forthcoming federal efficiency standards that are being 
developed for a wide range of commercial refrigeration equipment will capture much of the savings projected in these studies, ${ }^{13}$

3) HVAC Equipment. The measures related to HVAC generally covered replacing packaged (roof-top) equipment or chiller with more efficient units or installing economizers. With regard to packaged units, the pending federal efficiency standards will largely capture this potential.

4) Office Equipment. The most significant measures considered by a majority of the studies involve power management of computer networks (including nighttime shutdown of desktop computers). Current network management systems, that require night-time file backup and automated software upgrades would appear incompatible with such power management activities.

5) Roofs, Walls, and Foundations. By and large, little consideration of opaque envelope upgrades was included in these studies. The 2002 California study included window film and "cool roofs." As shown in Table 3.2, the window film is likely only marginally cost effective and the levelized cost of a cool roof was estimated to be more $\$ 0.20$ per $\mathrm{kWh}$.

6) Windows. The study by NWPPC considered window replacement with "high performance” glass (retrofitting single-glazed windows in electrically-heating buildings). The energy savings potential of this measure was estimated to be about 2 percent of the total potential for existing buildings.

In addition to the general categories of technologies listed above, it should be noted that the application of automated sensors and controls, along with building commissioning, has the potential to further reduce energy use in existing building. While not addressed in this study, this topic is quite extensive. ${ }^{14}$ With the exception of building commissioning, the data to support the types of cost-effective measures considered above is limited. In terms of technical potential, our best judgment at this point is that these measures may add an additional 5 to $20 \%$ to the retrofit potential to that considered in this study. ${ }^{15}$ As

\footnotetext{
13 The federal efficiency standards would impact new and replacement systems. The state and utility programs may capture some of this potential earlier because they provide incentives for early replacement and retrofits.

${ }^{14}$ With the exception of the NWPPC study, little mention in was made the studies summarized in Section 4 of the potential for these technologies (apart from daylighting and occupancy controls). In large part, this omission may result from the complexity in trying to define an incentive program that would promote adoption of such systems.

${ }^{15}$ For readers seeking more information on the potential of sensors, controls, and commissioning, several studies may be recommended. The first study was a comprehensive analysis of the potential of sensors and controls performed for the Buildings Technology office (Roth et al. 2005) and suggests that all types building controls and diagnostics may have the potential of reducing energy use in the range of 10 to 30 percent. The TIAX report suggested that "a combination of selected controls and diagnostics approaches ... could reduce commercial building energy consumption by between 2.3 and 6.5 quads per year.” See Table 2-2 in the TIAX report for a rough breakdown of the estimated savings by type of approach. We explicitly excluded the potential from commissioning from this table (the authors themselves recognized a
} 
automated sensors and controls can, in effect, lead to continuous commissioning, the estimates of savings potential in the two studies may still overlap to a considerable degree. $^{16}$ The point here is that, while not considered in the current study, the potential additional savings of improved control systems and diagnostic measures to ensure that buildings operate more efficiently is likely to remain large.

degree of double counting across some of categories of measures). In addition to commissioning, savings potential was also estimated for occupancy and daylighting sensors for lighting, and thus overlaps to some degree the potential in the studies considered above. Excluding these lighting-related controls, the study suggests that the impact of other types of sensors and controls (e.g., automated fault detection diagnostics, demand control ventilation, and optimal whole building controls) is still likely to range between 5 and $20 \%$.

\footnotetext{
${ }^{16}$ The second recommended study was performed by researchers from Lawrence Berkeley National Laboratory - The Cost-Effectiveness of Commercial Building Commissioning (Mills et al. 2004). Based upon a compilation of prior studies, the Mills et al. report indicated that the median savings in existing buildings was $15 \%$, with a payback of less than one year.
} 


\section{References}

American Society of Heating, Refrigerating and Air-Conditioning Engineers (ASHRAE) and Illuminating Engineering Society of North America (IESNA). 1999. ASHRAE Standard, Energy Standard for Buildings Except Low-Rise Residential Buildings.

Belzer, D.B. 2007. Estimates of U.S. Commercial Building Electricity Trends: Issues Related to End-Use and Supply Surveys. PNNL-16820. Richland, WA.

Commonwealth Edison. 2007. Commonwealth Edison Company’s 2008-2010 Energy Efficiency and Response Plan. Submitted to Illinois Commerce Commission under Docket No. 07-0540 (available under e-Docket, www.icc.illinois.gov/e-docket/)

GDS Associates and Quantum Consulting. 2004. Independent Assessment of Conservation and Energy Efficiency Potential for Connecticut and the Southwest Connecticut Region, Final Report. Prepared for the Connecticut Energy Conservation Management Board, June 2004, Marietta, GA.

GDS Associates. 2006. Vermont Electric Energy Efficiency Potential Study. Prepared for Vermont Department of Public Service, July 2006, Marietta, GA. http://www.state.vt.us/psb/document/ElectricInitiatives/AllAppendicesRevised.pdf

KEMA. 2006. Colorado DSM Market Potential Assessment, Vols. 1 \& 2. Report prepared for Xcel Energy (Denver, CO). KEMA, Oakland, CA.

http://www.xcelenergy.com/docs/corpcomm/CODSMMktPotentialVol1-20060331.pdf http://www.xcelenergy.com/docs/corpcomm/CODSMMktPotentialVol2-20060331.pdf

Mills et al. 2004. The Cost-Effectiveness of Commercial Building Commissioning. LBNL-56637 (Rev.) Lawrence Berkeley National Laboratory. Berkeley, CA.

NEOS Corporation. 1994. Technology Energy Savings, Volume 1: Baseline Energy Use Characteristics, prepared for the California Energy Commission, Sacramento, CA, May.

NEOS Corporation. 1994. Technology Energy Savings, Volume 2: Building Prototypes, prepared for the California Energy Commission, Sacramento, CA, May.

NEOS Corporation. 1994. Technology Energy Savings, Volume 1: Measure Definition and Impact Estimation Methodology, prepared for the California Energy Commission, Sacramento, CA, May.

Northeast Utilities System (1999). 1999 Express Service Program Impact Evaluation Final Report. Northeast Utilities Service Company. Berlin, CT. 
Northwest Power Planning Council. 2005. The Fifth Northwest Power and Conservation Plan. Northwest Power Planning Council, Portland, OR.

http://www.nwppc.org/energy/powerplan/5/Default.htm

Roth et al. 2005. Energy Impact of Commercial Building Controls and Performance Diagnostics: Market Characterization, Energy Impact of Building Faults and Energy Savings Potential. Prepared for U.S. D.O.E. Building Technologies Program, November 2005.

Sezgen, Osman and Jonathan Koomey. 1995. Technology Data Characterizing Refrigeration in Commercial Buildings: Application to End-Use Forecasting with COMMEND 4.0. LBNL-37397. Lawrence Berkeley National Laboratory, Berkeley, CA.

Xenergy. 2002a. California Statewide Commercial Energy Efficiency Potential Study, Volume 1. Prepared for Pacific Gas and Electric Company by Xenergy, Inc., Burlington, MA.

Xenergy. 2002b. California Statewide Commercial Energy Efficiency Potential Study, Volume 2. Prepared for Pacific Gas and Electric Company by Xenergy, Inc., Burlington, MA. 


\section{APPENDIX}

Comparison of Linear Fluorescent Cost Effectiveness Across Studies 


\section{Appendix - Comparison of Linear Fluorescent Cost Effectiveness Across Studies}

Lighting measures are the predominant energy efficiency in nearly all of the studies reviewed for this report. However, a closer look at the measures related to linear fluorescent lighting reveals some significant differences across the studies, particularly in the cost effectiveness of lighting retrofits. The difficulty in assessing lighting potential is that there are variety of measures that can reduce fluorescent lighting consumption, including the installation of : 1) standard T8 fixtures, 2) "Super" or premium T8 fixtures, 3) T-8 fixtures combined with de-lamping, and 3) T8 fixtures with reflectors. The applicability, as well as the cost effectiveness, of these measures will vary by building type (intensity of usage).

Table A.1 presents a rough comparison of some the values used with respect to T8 lamps in 2-lamp, 4-foot fixtures. As shown in Figure 3.10, this type of lighting fixture is the predominant fixture in the commercial sector. To the extent possible, the values were taken from the large office category, when the building type was specified in the study.

The yellow highlighted areas of the table indicate where the levelized cost has been recomputed for purpose of the comparison. The levelized cost values were derived from the assumption of a 5.6 percent real discount rate, a rate used in several studies (Connecticut and Vermont).

A close examination of the tables shows several areas in which there is substantial incongruity among the various studies.

1) T12 to T8/electronic ballast. This measure has been the principal lighting retrofit since the early 1990s. Four of the studies report values that allow comparison of the levelized cost of this retrofit. These measures are shown in rows (identified under row ID in column 1 of Table A.1): 1, 3, 6, and 10. The lowest levelized cost is from the Connecticut study (Row ID 3) of $\$ 0.038$ per $\mathrm{kWh}$, and the highest cost is from the NWPPC study at almost $\$ 0.14$ per $\mathrm{kWh}$. While it appears that the incremental costs of the fixtures are reasonably similar across the studies, the estimated annual kWh savings have considerable variation.

2) T8 to Super (Premium) T8. Three studies present data or direct estimates of the levelized cost for this retrofit (see Row ID’s 4, 8, and 12). There is reasonably good agreement on this measure as being highly cost-effective with levelized costs ranging from \$0.015 and \$0.03 per kWh saved. An unresolved question for several of the studies (Connecticut and ComEd) is whether the reported costs are the full cost of the Super/premium T8 system or just the incremental cost (The Connecticut study reports $\$ 10$ as a retrofit cost and the ComEd study reports only $\$ 4)$. The full cost, which would be much higher than $\$ 10$, would be appropriate for a retrofit situation; replacing a T8 
lamp and ballast, with a premium T8 lamp and new ballast. In this case, the cost effectiveness would not be as low as shown in the table.

3) Reflector fixtures. The 2002 California study suggests that going from two T12 lamps to one T8 lamp and a reflector is highly cost effective, with an estimated levelized cost of less than $\$ 0.01$ per kWh (Row ID 2 in Table A.1). This estimate is in sharp contrast to the ComEd estimate (Row ID 13) of nearly $\$ 0.05$ for the same type of retrofit. The Connecticut study indicates the cost effectiveness of a Super T8 system using a reflector, compared to a conventional T8 fixture (Row ID 5). The cost effectiveness of this retrofit is also considerably higher, and closer to the ComEd study, at over $\$ 0.05$ per $\mathrm{kWh}$ saved. As mentioned in the main report, the Colorado study addressed the issue of how much commercial floor space may be considered viable for reflector fixtures (less than 50\%).

A more complete rationalization of these alternative estimates is beyond the scope of this study. On the surface, it would appear that the evaluation of cost-effective lighting measures would be straightforward. The discussion reveals a wide disparity of estimates across studies, even when the substitution of conventional and efficient lighting systems is considered on a one-for-one basis. In reality, actual lighting retrofits have typically involved both delamping and more efficient technologies. Thus, the one-for-one technology replacement generally does not represent real world experience.

Because the lighting levels have been reduced in the more recent ASHRAE/IESNA commercial building standards, these reductions have been also reflected in lower illumination levels in lighting retrofits in existing buildings (either informally or to achieve code compliance for major building renovations). Thus, future reductions in lighting use will be more difficult in those buildings that have already adopted T8s and electronic ballasts, because these earlier retrofits likely involved some reduction in illumination levels as well.

Table A.1. Comparison of Cost and Efficiency Assumptions for Linear Fluorescent Lighting Measures 


\begin{tabular}{|c|c|c|c|c|c|c|c|c|}
\hline $\begin{array}{l}\text { Row } \\
\text { ID }\end{array}$ & Base Technology & Efficient Technology & $\begin{array}{c}\text { Fixturel } \\
\text { Lamp } \\
\text { Cost }\end{array}$ & $\begin{array}{l}\text { Levelized } \\
\text { Cost of } \\
\text { Measure }\end{array}$ & $\begin{array}{c}\text { Annual } \\
\text { kWh } \\
\text { Savings }\end{array}$ & $\begin{array}{l}\text { Levelized } \\
\text { cost/kWh }\end{array}$ & $\begin{array}{l}\text { Measure } \\
\text { Life (yrs) }\end{array}$ & Notes \\
\hline \multicolumn{9}{|c|}{ California Commercial Sector Study (2002) } \\
\hline & & & & & & & & $\begin{array}{l}\text { Detailed data is } \\
\text { confusing (used } \\
\text { reported levelized } \\
\text { costs from }\end{array}$ \\
\hline 2 & $\begin{array}{l}24 \text { 4' T12 } 34 \text { watt lamps w/MB } \\
\text { ciency Potential Study }\end{array}$ & RET 1 4' T8 32 watt lamps with EB, refleı & $\$ 37$ & & $57 \%$ & $\$ 0.020$ & 14 & " \\
\hline & & & & & & & & $\begin{array}{l}\text { This and measure } \\
\text { below assume }\end{array}$ \\
\hline 3 & $34 \mathrm{~W}$ T12 & RET 2L4' T8 & $\$ 27$ & $\$ 2.71$ & 72 & $\$ 0.038$ & 15 & $\begin{array}{l}3,000 \text { hours/yr. } \\
\text { Cost is presumed }\end{array}$ \\
\hline 4 & Standard T8 fixture & RET 2L4' Super T8, 1 EB & $\$ 10$ & $\$ 1.00$ & 36 & $\$ 0.028$ & 15 & to be incremental \\
\hline 5 & Standard T8 fixture & RET 2L4' Super T8, 1 EB, reflector & $\$ 45$ & $\$ 4.51$ & 84 & $\$ 0.054$ & 15 & \\
\hline \multicolumn{9}{|c|}{ NWPPC 2005 Plan } \\
\hline 6 & $\begin{array}{l}\text { 2-4ft, 34/40w, T-10/12 Lamp \& } \\
\text { Mag. Ballast }\end{array}$ & T-8 EB & $\$ 34$ & $\$ 3.97$ & 29.6 & $\$ 0.134$ & 12 & $\begin{array}{l}\text { Spreadsheet } \\
\text { ComLighting_v200 } \\
\text { 4_1, worksheet } \\
\text { L\&B Retro } \\
\text { Deemed Measure } \\
\text { Table }\end{array}$ \\
\hline \multicolumn{9}{|c|}{ VT Efficiency Study } \\
\hline 7 & 34 watt T12 & Super T8 fixture & NA & $\$ 4.33$ & 173 & $\$ 0.025$ & 15 & Appendix B-1 \\
\hline 8 & Standard T8 & Super T8 fixture & NA & $\$ 1.67$ & 77 & $\$ 0.022$ & 15 & Appendix B-1 \\
\hline 9 & (Implied: 34 watt T12) & (Implied: Standard T-8) & NA & $\$ 2.66$ & 96 & $\$ 0.028$ & & \\
\hline \multicolumn{9}{|c|}{ Commonwealth Edison Energy Efficiency and Demand Response Plan } \\
\hline 10 & 2 4' T12 34 watt lamps w/MB & 2 4' T8 32 watt lamps with EB & $\$ 29$ & $\$ 3.60$ & 46 & $\$ 0.078$ & 11 & $\begin{array}{l}\text { Appendix } B \text {, for } \\
\text { large office } \\
\text { Appendix } B \text {, for }\end{array}$ \\
\hline 11 & 2 4' T12 34 watt lamps w/MB & 2 4' Super T8 28 watt lamps with EB & $\$ 33$ & $\$ 4.10$ & 79 & $\$ 0.052$ & 11 & $\begin{array}{l}\text { large office } \\
\text { Appendix } B \text {, for }\end{array}$ \\
\hline 12 & 2 4' T8 32 watt lamps with EB & 24 ' Super T8 28 watt lamps with EB & $\$ 4$ & $\$ 0.50$ & 33 & $\$ 0.015$ & 11 & $\begin{array}{l}\text { large office } \\
\text { Appendix B, for }\end{array}$ \\
\hline 13 & 2 4' T12 34 watt lamps w/MB & 14 ' T8 32 watt lamp, with EB, reflector & $\$ 50$ & $\$ 6.21$ & 128 & $\$ 0.049$ & 11 & large office \\
\hline \multicolumn{9}{|c|}{ Colorado DSM Market Potential Assessment } \\
\hline & & & & & & & & $\begin{array}{l}\text { For cost, } \$ 25 \\
\text { represents the } \\
\text { base } T-12 \text {, }\end{array}$ \\
\hline 14 & 2L4' T12, 1 EEMAG & RET 2L4' Premium T8, 1 EB & $\$ 25+\$ 11$ & & $31 \%$ & & $70,000 \mathrm{hrs}$ & EEMAG system \\
\hline 15 & 2L4' T12, 1 EEMAG & RET 1L4' Premium T8, 1 EB, reflector & $\$ 25+\$ 24$ & & $64 \%$ & & $70,000 \mathrm{hrs}$ & " \\
\hline
\end{tabular}

